\title{
Evaluation of a previous mass campaign against endemic syphilis in Bosnia and Herzegovina
}

\author{
E. I. GRIN AND T. GUTHE \\ Sarajevo, Yugoslavia
}

It is now almost 30 years since penicillin was introduced to combat the endemic treponematoses of childhood, prevalent in rural areas of many developing countries. Preparations such as PAM and benzathine penicillin were shown to produce effective blood and tissue concentrations of 4 days' to 3 weeks' duration after single intramuscular injections. Long-acting treatment thus became available which could be used on clinical as well as epidemiological indications, and organized community-wide campaigns could be undertaken in endemic treponematoses areas. This development gave hope that disease could be eliminated by the wide use of a drug alone.

On the basis of pilot studies of yaws in Haiti (Levitan, Rodriguez, Jacobs, Petrus, and Durand, 1953), endemic childhood syphilis in Yugoslavia (Grin, 1953), and pinta in Mexico (Edmundson, Lopez, Rico, and Olansky, 1953), mass penicillin campaigns were undertaken by health administrations in 46 countries in the context of the WHO Treponematoses Programme. In the first decade national and international attention was focused on the setting up of a programme and on control of disease. With declining clinical prevalence, orientation turned towards concurrent epidemiological surveillance. In the last few years seroepidemiological studies of the changing pattern of disease and infection became possible and a method-

Received for publication June 6, 1972

This article was originally prepared as an internal unpublished document by the World Health Organization (INT/VDT/72.319) under the title: "A sero-epidemiological evaluation study on the outcome of a previous endemic syphilis campaign in Bosnia and Herzegovina'. The document was a report issued jointly by the following participants in the project: Institute of Dermato-Venereology Sarajevo (Prof. E. I. Grin, Dr. M. Nadazdin); WHO Interregional Treponematoses Research Team (Dr. F. Vorst, Mr. J. D' Costa, Mr. J. Maxwell); WHO headquarters (Dr. T. Guthe, VDT; Dr. J. Ridet; Dr. B. Grab, HSM); WHO International Reference Centres (State Serum Institute, Copenhagen, Dr. H. Aa Nielsen; Institut Alfred Fournier, Paris, Prof. A. Vaisman; VDRL laboratory, Center for Disease Control, USPHS, Atlanta, Dr. L. Norins).

Address for reprints: Prof. E. I. Grin, Institute of Dermatovenereology, Sarajevo P.O. Box 137 Yugoslavia.

ology for long-term surveillance of endemic trepo- 윽 nematoses was developed in the frame of the activities of the World Health Organization. The present 7 paper is concerned with the application of this $\frac{\mathbb{D}}{2}$ methodology and the study of 'disappearing' disease in regard to the endemic treponematosis of childhood, known as 'endemic non-venereal syphilis', $\vec{v}$ previously prevalent in the Federal Republic of $\omega$ Bosnia-Herzegovina, Yugoslavia.

It may first be useful to recall that endemic syphilis is a disease acquired by non-venereal contact, predominantly in childhood, characterized by infec- $\bar{\partial}$ tious mucous membrane and relapsing skin lesions in $\frac{0}{D}$ the first years of its natural course. In adolescence and $\cong$ adult life, late, sometimes incapacitating and mutilat- $\overrightarrow{\overrightarrow{0}}$ ing, lesions of skin, bones, and joints may develop. 3 Cardiovascular and nervous system involvement are rare, and when present are mostly mild and non-? progressive.

Early latency and late latency are much more fre- $\frac{\dot{\sigma}}{2}$ quent than clinical disease in endemic areas. These latent cases, as well as those with clinical lesions, are of seroreactive in tests using lipoidal and treponemal $₹$ antigens (e.g. the Wassermann reaction (WR), the 은 Venereal Disease Research Laboratory (VDRL) test, $\rightarrow$ the fluorescent treponemal antibody (FTA) test, and the Treponema pallidum immobilization (TPI) test. Serological response to therapy is related to the $\mathrm{N}$ duration of the infection. Seroreactivity may remain $N$ in endemic syphilis as in other treponematoses $\underset{\mathrm{N}}{N}$ throughout life in untreated persons and often also in 0 persons adequately treated in the later stages of the disease.

Secondly, it may be recalled that, when therapy of $\stackrel{\mathcal{P}}{?}$ the treponematoses depended on multiple injections $\square$ of arsenicals and/or bismuth, mass campaigns were $\stackrel{\circ}{\circ}$

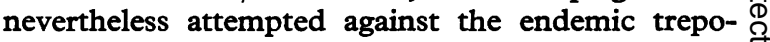
nematoses in several countries. Treatment surveys $\mathbb{D}$ and re-surveys were undertaken in rural populations and information was obtained on the nature, extent, distribution, and pattern of disease. Such epidemiological data were, for example, collected on yaws in 
Western Pacific islands as early as 1923 and in subsequent years (Buxton, 1928; Lambert, 1936), and in Africa (Harding, 1949), as well as on endemic syphilis in Yugoslavia (Grin, 1937; Kogoj and Vuletic, 1939). However, the epidemiological concept that treatment was necessary for symptomless household contacts and presumed latent cases in addition to clinical cases had as yet not evolved. Demographic aspects were not taken adequately into account in early campaigns, nor was the epidemiological importance of obtaining complete coverage of the total population recognized. Such quantitative aspects are today held to be essential elements of mass campaigns and of the methodology of epidemiological surveillance.

In general, several periodical re-surveys (RS) are undertaken after the initial treatment survey (ITS) of mass campaigns against the endemic treponematoses. From the findings in the mass campaigns and the concurrent surveillance studies of endemic treponematoses certain questions arise:

Can early infectious clinical disease actually be eliminated, and can transmission of infection be interrupted through the wide application of a drug, utilized in accordance with the epidemiological characteristics of the disease?

\section{The endemic syphilis of Bosnia and the mass- treatment campaign, 1948-1955}

Since the first published description of endemic syphilis ('non-venereal endemic syphilis') in BosniaHerzegovina by Glück (1888), the origin, extent, and changing pattern of this disease have been the subject of many national and international studies. These are not reviewed in the present report, which refers only to recent investigations of this endemic disease after a penicillin mass treatment programme which was begun in 1948. The programme has been described in some detail by Grin (1953, 1960), Clark (1950), Guthe and Luger (1966), and others. Grin also described the changing socioeconomic conditions of the population in the endemic areas as well as the relevant cultural and other background features which affect the epidemiology and control of endemic treponematosis.

The campaign, which was conducted between 1948 and 1955 by the health administration of the Republic of Bosnia-Herzegovina and the federal health authorities of Yugoslavia, with technical and other assistance from the World Health Organization (WHO) and the United Nations Children's Fund (UNICEF), aimed at the eradication of this endemic treponematosis of childhood which had been prevalent in large areas of the Republic since the 18th century (Fig. 1).

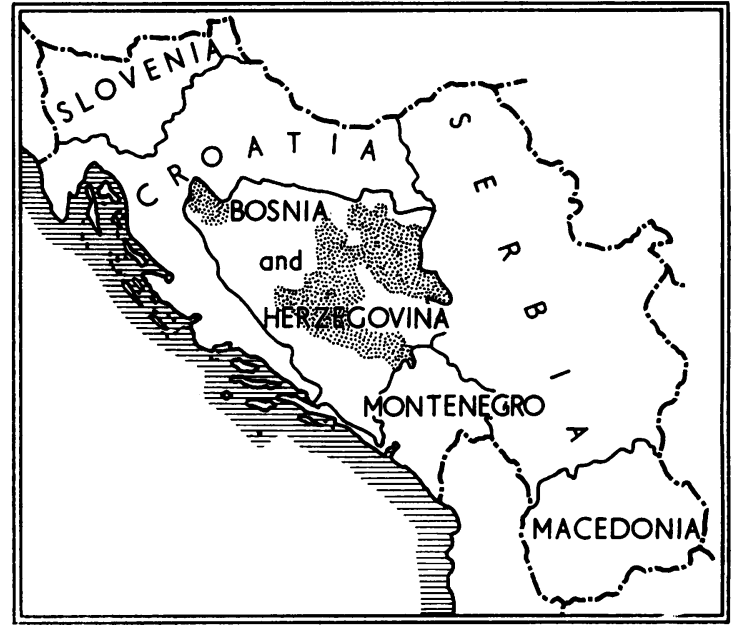

FIG. 1 Prevalence of endemic syphilis in Bosnia and Herzegovina, 1951

The methodology used in the campaign has been described in the publications mentioned as well as in reports by WHO Expert Committees (WHO, 1953, 1960). Briefly, the methodology was based on an initial examination of the population concerned at ITS, with treatment of overt clinical and latent cases and their household contacts, followed by periodical -RS of the populations at risk, in both instances using defined dosage schedules of long-acting procaine penicillin $G$ in oil with aluminium monostearate (PAM).

The coverage of the population in the ITS of the mass campaign-during which more than 600,000 people were examined-ranged from 50.1 to 99.6 per cent. of the enumerated population in different areas (Table I and Fig. 2). An average of 79.2 per cent. of the population at risk was examined. The clinical and serological findings at the ITS and succesive RSs in the population covered by the mass campaign 19481955 and on subsequent surveillance (1956-1967) are presented in Table II(a, b, c, d, e) (overleaf). At ITS, infectious lesions ranged from 0 to 4.4 per cent. and seroreactivity from 0.75 to 16.6 per cent. in the different administrative units ${ }^{\star}$ as a whole. There were great variations in the endemicity of the disease between the different smaller units and villages in one Srez and between the different Srez. In some villages the incidence of infectious lesions was as high as 14 per cent. (as in Sokol) and that of seroreactors was more than 50 per cent. (as in Brushnica). This pattern is characteristic of endemic syphilis, and foci of high prevalence are often found next to areas of very low prevalence. This aspect is illustrated in Fig. 3.

*The local name for an administrative unit is Srez. 
TABLE I Population coverage at the initial survey (ITS), 1948-56

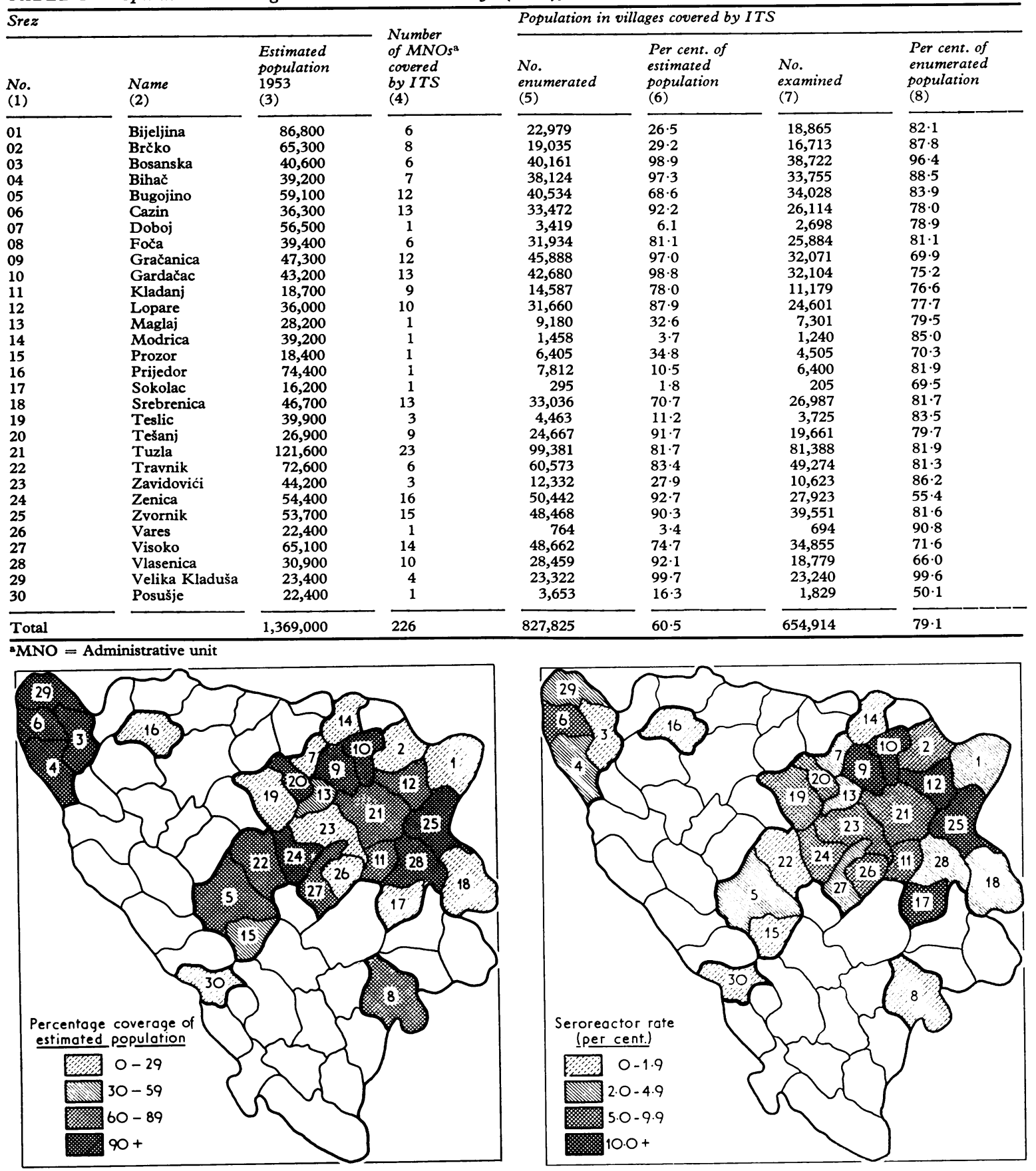

FIG. 2 Proportion of population covered by the initial treatment survey (ITS) in each Srez. The numbers correspond to the Srez code as given in Table I
FIG. 3 Average seroreactor rate in the initial treatment survey (ITS) in each Srez 
T A B L E I I Clinical and serological findings in population covered by mass campaign

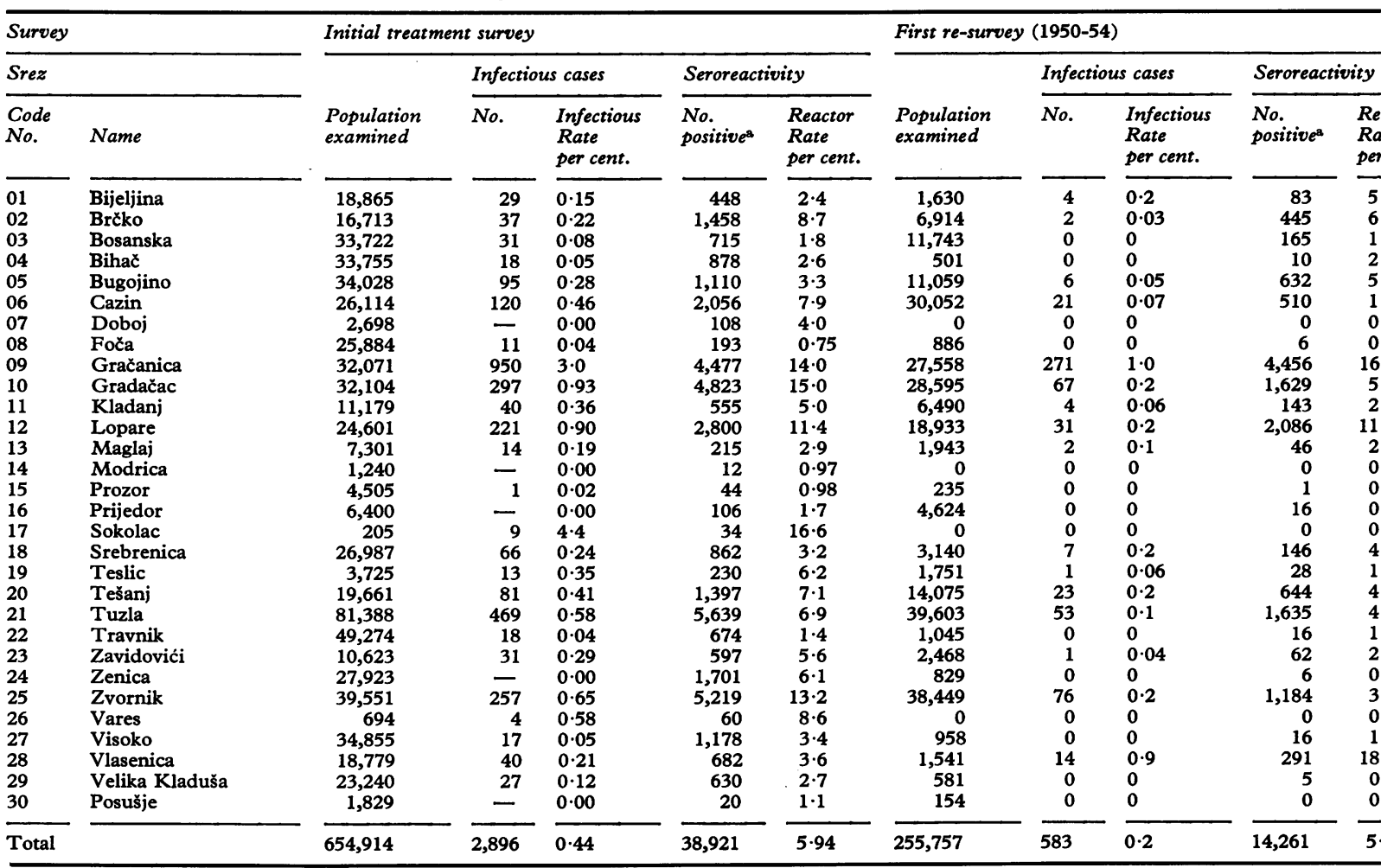

aIncluding weakly positive

Table II(e) shows that it was necessary to follow up only six Srez with a fourth RS, during which a total of approximately 21,000 people were examined. After 1955, surveillance activities were undertaken in periodical RS in the previously infected areas, either as separate actions or integrated in the activities of a subsequent antimycosis campaign (Grin, 1961). A more detailed picture of the regression of endemic syphilis after the mass penicillin campaigns, not only in the Srez of Bosnia-Herzegovina but also in the villages themselves, is presented in Table III, showing the findings at the ITS and at the last re-survey (LRS) after completion of the campaign in twenty villages situated in nine regions. The complete disappearance of active lesions and the decreased rate of seroreactivity emphasize the effectiveness of the mass campaign. There can be little doubt that the effect has been conspicuous throughout the endemic syphilis areas in Bosnia both as regards clinical cases and seroreactivity, indicating complete eradication of the infection. The WHO Expert Committee on Venereal Infections and Treponematoses (WHO Technical Report Series No. 190, 1960) defined two stages of eradication: 'epidemiological eradication' and 'complete eradication'. The former was recognized as the stage at which no indigenous infectious case of treponematosis had appeared in the population for 3 consecutive years, in accordance with certain criteria established for casefinding. 'Complete eradication' would require that no active case appeared in the population for 3 years and that no seroreactors were found among children under 5 years of age-again in accordance with certain criteria for casefinding. Serological investigations of endemic treponematoses after mass campaigns are thus necessary in order to evaluate the effect of the campaign.

\section{Post mass-campaign evaluation study}

An agreement to carry out a representative seroepidemiological study of the endemic treponematoses of Bosnia-Herzegovina 20 years after the beginning of the campaign was signed between the Federal Government of Yugoslavia, the Government of the Republic of Bosnia-Herzegovina, and WHO in 1967. With collaboration between the Institute of Dermato- 


\begin{tabular}{|c|c|c|c|c|c|c|c|c|c|c|c|c|c|c|}
\hline \multicolumn{5}{|c|}{ d re-survey (1951-54) } & \multicolumn{5}{|c|}{ Third re-survey (1953-54) } & \multicolumn{5}{|c|}{ Fourth re-survey (1953-55) } \\
\hline \multirow[b]{2}{*}{$\begin{array}{l}\text { ation } \\
\text { ned }\end{array}$} & \multicolumn{2}{|c|}{ Infectious cases } & \multicolumn{2}{|c|}{ Seroreactivity } & \multirow[b]{2}{*}{$\begin{array}{l}\text { Population } \\
\text { examined }\end{array}$} & \multicolumn{2}{|c|}{ Infectious cases } & \multicolumn{2}{|c|}{ Seroreactivity } & \multirow[b]{2}{*}{$\begin{array}{l}\text { Population } \\
\text { examined }\end{array}$} & \multicolumn{2}{|c|}{ Infectious cases } & \multicolumn{2}{|c|}{ Seroreactivity } \\
\hline & No. & $\begin{array}{l}\text { Infectious } \\
\text { Rate } \\
\text { per cent. }\end{array}$ & $\begin{array}{l}\text { No. } \\
\text { positive }\end{array}$ & $\begin{array}{l}\text { Reactor } \\
\text { Rate } \\
\text { per cent. }\end{array}$ & & No. & $\begin{array}{l}\text { Infectious } \\
\text { Rate } \\
\text { per cent. }\end{array}$ & $\begin{array}{l}\text { No. } \\
\text { positivea }\end{array}$ & $\begin{array}{l}\text { Reactor } \\
\text { Rate } \\
\text { per cent }\end{array}$ & & No. & $\begin{array}{l}\text { Infectious } \\
\text { Rate } \\
\text { per cent. }\end{array}$ & $\begin{array}{l}\text { No. } \\
\text { positive }\end{array}$ & $\begin{array}{l}\text { Reactor } \\
\text { Rate } \\
\text { per cent. }\end{array}$ \\
\hline 0 & 0 & 0 & 0 & 0 & 0 & 0 & 0 & 0 & 0 & 0 & 0 & 0 & 0 & 0 \\
\hline 31 & 9 & $0 \cdot 2$ & 129 & $3 \cdot 5$ & 0 & 0 & 0 & 0 & 0 & 0 & 0 & 0 & 0 & 0 \\
\hline 0 & 0 & 0 & 0 & 0 & 0 & 0 & 0 & 0 & 0 & 0 & 0 & 0 & 0 & 0 \\
\hline 0 & 0 & 0 & 0 & 0 & 0 & 0 & 0 & 0 & 0 & 0 & 0 & 0 & 0 & 0 \\
\hline 66 & 0 & 0 & 3 & $1 \cdot 1$ & 0 & 0 & 0 & 0 & 0 & 0 & 0 & 0 & 0 & 0 \\
\hline 41 & 0 & 0 & 1 & 0.2 & 0 & 0 & 0 & 0 & 0 & 0 & 0 & 0 & 0 & 0 \\
\hline 0 & 0 & 0 & 0 & 0 & 0 & 0 & 0 & 0 & 0 & 0 & 0 & 0 & 0 & 0 \\
\hline 0 & 0 & 0 & 0 & 0 & 0 & 0 & 0 & 0 & 0 & 0 & 0 & 0 & 0 & 0 \\
\hline 40 & 58 & $0 \cdot 2$ & 1,627 & $4 \cdot 8$ & 40,864 & 30 & 0.07 & 841 & $2 \cdot 1$ & 11,428 & 13 & $0 \cdot 1$ & 392 & $3 \cdot 4$ \\
\hline 72 & 12 & 0.04 & 623 & 1.9 & 692 & 0 & 0 & 17 & $2 \cdot 5$ & 0 & 0 & 0 & 0 & 0 \\
\hline 50 & 3 & $0 \cdot 7$ & 23 & $5 \cdot 1$ & 319 & 0 & 0 & 3 & 0.9 & 360 & 0 & 0 & 8 & $2 \cdot 2$ \\
\hline 52 & 4 & 0.02 & 386 & 1.6 & 18,465 & 2 & 0.01 & 304 & 1.6 & 2,686 & 1 & 0.04 & 77 & 2.9 \\
\hline 94 & 0 & 0 & 38 & $5 \cdot 6$ & 0 & 0 & 0 & 0 & 0 & 0 & 0 & 0 & 0 & 0 \\
\hline 0 & 0 & 0 & 0 & 0 & 0 & 0 & 0 & 0 & 0 & 0 & 0 & 0 & 0 & 0 \\
\hline 0 & 0 & 0 & 0 & 0 & 0 & 0 & 0 & 0 & 0 & 0 & 0 & 0 & 0 & 0 \\
\hline 0 & 0 & 0 & 0 & 0 & 0 & 0 & 0 & 0 & 0 & 0 & 0 & 0 & 0 & 0 \\
\hline 0 & 0 & 0 & 0 & 0 & 0 & 0 & 0 & 0 & 0 & 0 & 0 & 0 & 0 & 0 \\
\hline 11 & 0 & 0 & 66 & $2 \cdot 6$ & 1,309 & 0 & 0 & 59 & 4.5 & 0 & 0 & 0 & 0 & 0 \\
\hline 0 & 0 & 0 & 0 & 0 & 0 & 0 & 0 & 0 & 0 & 0 & 0 & 0 & 0 & 0 \\
\hline 34 & 0 & 0 & 120 & $4 \cdot 2$ & 0 & 0 & 0 & 0 & 0 & 0 & 0 & 0 & 0 & 0 \\
\hline 15 & 34 & $0 \cdot 1$ & 890 & $3 \cdot 4$ & 7,428 & 1 & 0.01 & 223 & $3 \cdot 0$ & 2,338 & 0 & 0 & 20 & 0.9 \\
\hline 75 & 0 & 0 & 0 & 0 & 0 & 0 & 0 & 0 & 0 & 0 & 0 & 0 & 0 & 0 \\
\hline 73 & 0 & 0 & 6 & $1 \cdot 3$ & 0 & 0 & 0 & 0 & 0 & 0 & 0 & 0 & 0 & 0 \\
\hline 0 & 0 & 0 & 0 & 0 & 0 & 0 & 0 & 0 & 0 & 0 & 0 & 0 & 0 & 0 \\
\hline 76 & 24 & $0 \cdot 1$ & 530 & $3 \cdot 2$ & 6,210 & 0 & 0 & 126 & $2 \cdot 0$ & 3,729 & 2 & 0.05 & 91 & $2 \cdot 4$ \\
\hline 0 & 0 & 0 & 0 & 0 & 0 & 0 & 0 & 0 & 0 & 0 & 0 & 0 & 0 & 0 \\
\hline 0 & 0 & 0 & 0 & 0 & 0 & 0 & 0 & 0 & 0 & 0 & 0 & 0 & 0 & 0 \\
\hline 72 & 9 & $9 \cdot 1$ & 53 & $5 \cdot 3$ & 504 & 1 & 0.2 & 43 & 8.5 & 916 & 1 & $0 \cdot 1$ & 51 & $5 \cdot 6$ \\
\hline 0 & 0 & 0 & 0 & 0 & 0 & 0 & 0 & 0 & 0 & 0 & 0 & 0 & 0 & 0 \\
\hline 0 & 0 & 0 & 0 & 0 & 0 & 0 & 0 & 0 & 0 & 0 & 0 & 0 & 0 & 0 \\
\hline 182 & 153 & $0 \cdot 1$ & 4,495 & $3 \cdot 0$ & 75,791 & 34 & 0.04 & 1,616 & $2 \cdot 1$ & 21,457 & 17 & 0.08 & 639 & $3 \cdot 0$ \\
\hline
\end{tabular}

TABLE III Results of the initial survey and last re-survey after completion of the campaign in selected villages *

\begin{tabular}{|c|c|c|c|c|c|c|c|c|c|c|c|c|c|}
\hline \multirow{2}{*}{ Region } & \multirow{2}{*}{ Village } & \multicolumn{6}{|c|}{ Initial survey } & \multicolumn{6}{|c|}{ Last re-survey after completion of the campaign } \\
\hline & & Year & $\begin{array}{l}\text { No. of } \\
\text { people } \\
\text { examined }\end{array}$ & \multicolumn{2}{|l|}{$\begin{array}{l}\text { Active } \\
\text { lesions }\end{array}$} & \multicolumn{2}{|c|}{ Seroreactive } & Year & $\begin{array}{l}\text { No. of } \\
\text { people } \\
\text { examined }\end{array}$ & \multicolumn{2}{|c|}{$\begin{array}{l}\text { Active } \\
\text { lesions }\end{array}$} & \multicolumn{2}{|c|}{ Seroreactive } \\
\hline \multirow[t]{2}{*}{ GRACANICA: } & Doborovci & 1948 & 1,930 & 128 & 30 & 468 & $24 \cdot 2$ & 1965 & 1,512 & 0 & 0 & 24 & 1.6 \\
\hline & Malesic & 1948 & 1,912 & 143 & 30 & 437 & $22 \cdot 9$ & 1961 & 1,915 & 0 & 0 & 71 & $3 \cdot 7$ \\
\hline \multirow{4}{*}{ ZVORNIK: } & Sibosnica & 1949 & 2,668 & 44 & 22 & 428 & $16 \cdot 0$ & 1964 & 2,432 & 0 & 0 & 63 & $2 \cdot 6$ \\
\hline & Dulici & 1949 & 158 & 0 & 0 & 22 & 13.9 & 1958 & 171 & 0 & 0 & 5 & 2.9 \\
\hline & Kamenica & 1949 & 589 & 3 & 7 & 85 & $14 \cdot 4$ & 1965 & 469 & 0 & 0 & 7 & 1.5 \\
\hline & Sapna & 1949 & 3,687 & 136 & 53 & 905 & $24 \cdot 5$ & 1958 & 3,386 & 0 & 0 & 44 & $1 \cdot 3$ \\
\hline \multirow[t]{2}{*}{ KLADANJ: } & Nocajevici & 1950 & 254 & 6 & 0 & 45 & $17 \cdot 7$ & 1963 & 360 & 0 & 0 & 8 & $2 \cdot 2$ \\
\hline & Tarevo & 1950 & 379 & 0 & 0 & 24 & $6 \cdot 3$ & 1964 & 516 & 0 & 0 & 7 & $1 \cdot 4$ \\
\hline VLASENICA: & Besici a. Nurici & 1950 & 182 & 1 & 1 & 16 & $8 \cdot 8$ & 1967 & 218 & 0 & 0 & 3 & $1 \cdot 4$ \\
\hline PRIJEDOR: & Kozarac & 1953 & 6,400 & 0 & 0 & 106 & $1 \cdot \overline{7}$ & 1963 & 4,624 & 0 & 0 & 16 & $0 \cdot 3$ \\
\hline Total & & & 25,756 & 719 & 237 & 4,049 & $15 \cdot 7$ & & 23,186 & 0 & 0 & 515 & $2 \cdot 2$ \\
\hline
\end{tabular}

*In the seroepidemiological survey 1968-1970 some of the villages shown in this Table fell into the randomly selected sample 
Venereology, Sarajevo, WHO headquarters, Geneva, and the WHO Regional Office for Europe, Copenhagen, this study was carried out from 1968 to 1970 . It was part of the agreement that the serum collections to be obtained would be utilized also for multiple investigations of infections and conditions other than treponematoses.

\section{OBJECTIVES}

These are outlined in the Survey Design and Working Protocol (INT/VDT/70.315).

(a) To evaluate the results of the previous mass campaign and the epidemiological trends of endemic treponematoses under the influence of mass treatment and of the rapid improvement of socio-economic conditions;

(b) To assess the effect of treatment in the community as a whole;

(c) To appraise, retrospectively, the effect of treatment in groups actually subjected to mass campaign measures;

(d) To undertake special clinical, laboratory and other examinations of persons still found to be seroreactive by the TPI test in the present survey;

(e) To exploit the serum collection obtained for conditions other than endemic treponematosis. *

\section{METHODOLOGY}

A representative sample of the population of the previous endemic areas was examined serologically by multiple treponemal and lipoidal antigen tests according to the detailed Survey Design and Working Protocol. The laboratory at the Institute in Sarajevo examined all sera. A subsample of twelve villages provided aliquots of sera which were sent to the WHO Reference Laboratory in Copenhagen for proficiency testing as part of an agreement with the Sarajevo Laboratory. A further proficiency testing study of the TPI test was undertaken between the Sarajevo Laboratory, the VDRL Reference Laboratory, Atlanta, and the State Serum Institute Reference

\footnotetext{
* The following subjects were studied in the multipurpose investigations of the Bosnian sera

(1) Tetanus immunity Gamaleya Institute of Epidemiology and Microbiology, Moscow (1,053 sera from six sample villages).

(2) Antistreptolysin-0, diphtheria, pertussis, and parapertussis Institute of Epidemiology and Microbiology, Prague (591 sera from selected age groups from eight sample villages).

(3) Arbovirus infections Department of Virology, School of Public Health, University of Zagreb $(2,115$ sera from fourteen sample villages).

(4) Rickettsial infections Department of Epidemiology, Medical Faculty, Sarajevo (1,041 sera from six sample villages).

(5) Malaria Nuffield Institute for Medical Research, London (300 sera from four sample villages).

(6) Human genetic factors Centre Départmental de Transfusion Sanguine, Rouen (760 sera from four sample villages).

The reports on these investigations are to be published separately.
}

Laboratory, Copenhagen, according to a special protocol established for the purpose.

\section{Sample design}

The sample to be examined consisted of clusters of 250 persons, in 48 sample villages with a total of some 12,000 persons. Since a meaningful stratification of the population to be examined was not possible, 48 villages out of the 1,605 villages in the whole survey area were selected, with probabilities proportional to their population size. The first village was chosen at random in the first 48th fraction of the total population. A further 47 villages were determined by periodical sampling at similar intervals. When comparing the seroreactor rates found in the 48 villages at ITS with the seroreactor rates of the administrative units (MNOs) to which the villages belonged, the 48 selected villages were found to form a good representative sample of he areas from which they were selected.

Table IV (opposite) lists the villages with the clinical and serological findings at ITS in the villages and the corresponding MNOs. Fig. 4 shows the geographical distribution of the selected villages.

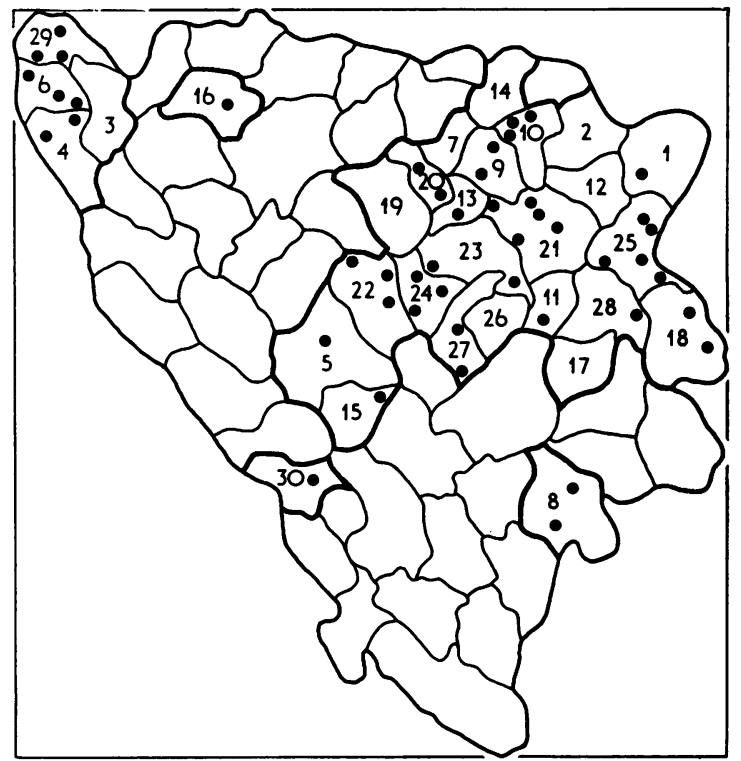

FIG. 4 Geographical distribution of the 48 selected villages

A satisfactory correlation between reactor-rates at ITS in the selected villages and the corresponding MNOs was found; this is shown in Fig. 5 (overleaf). 
TABLE IV Basic findings at ITS in the selected villages and the corresponding MNOs

\begin{tabular}{|c|c|c|c|c|c|c|c|c|}
\hline $\begin{array}{l}\text { Selected } \\
\text { village } \\
\text { no. }\end{array}$ & $\begin{array}{l}\text { Srez } \\
\text { code } \\
\text { number }\end{array}$ & \multicolumn{4}{|c|}{ MNO out of which village was selected } & \multicolumn{3}{|c|}{ Selected village } \\
\hline 1 & 01 & 04 & Ugljevik & $0 \cdot 29$ & $2 \cdot 2$ & 07 & Dragovići & $2 \cdot 8$ \\
\hline 2 & 04 & 01 & Vrsta & 0.05 & $5 \cdot 6$ & 08 & Mala Peča & $5 \cdot 6$ \\
\hline 3 & 04 & 02 & Pokoj & 0.05 & $2 \cdot 1$ & 02 & Srbljani & $2 \cdot 5$ \\
\hline 6 & 20 & 04 & Piljozići & 0.61 & $6 \cdot 2$ & 02 & Lončari & 0.60 \\
\hline 7 & 20 & 13 & Stijena & $1 \cdot 1$ & $9 \cdot 4$ & 01 & Podgredina & 10.9 \\
\hline 8 & 08 & 03 & Ustikolina & $0 \cdot 11$ & 0.92 & 03 & Paunči & 0.0 \\
\hline 9 & 08 & 06 & Sutješka & 0.04 & 0.62 & 02 & Djedjevo & $0 \cdot 40$ \\
\hline 10 & 09 & 03 & Petrovo Selo & 0.00 & $1 \cdot 3$ & 04 & Krtova & $2 \cdot 1$ \\
\hline 11 & 09 & 07 & Sladna & $4 \cdot 6$ & 25.0 & 05 & Pirage & $25 \cdot 7$ \\
\hline 12 & 10 & 03 & Zelinja Gornja & $1 \cdot 7$ & $22 \cdot 8$ & 02 & Jasenice & $17 \cdot 5$ \\
\hline 13 & 10 & 10 & Vida & 0.37 & $19 \cdot 1$ & 01 & Novalići & 33.0 \\
\hline 19 & 18 & 02 & Srebrenica & $0 \cdot 11$ & $2 \cdot 6$ & 04 & Dimnići etc. & $2 \cdot 8$ \\
\hline 20 & 18 & 03 & Bratunac & 0.06 & $2 \cdot 4$ & 07 & Bljeceva & $0 \cdot 28$ \\
\hline 21 & 20 & 07 & Jelah & 0.07 & $1 \cdot 6$ & 02 & Jevadzije & $2 \cdot 6$ \\
\hline 22 & 20 & 06 & Kalosevic & 0.57 & $5 \cdot 3$ & 02 & Kalosevic & 4.8 \\
\hline 23 & 21 & 05 & Banovici & $1 \cdot 0$ & $7 \cdot 9$ & 02 & Trestenica etc. & $11 \cdot 6$ \\
\hline 24 & 21 & 08 & Tojsic & $0 \cdot 77$ & $7 \cdot 3$ & 07 & Gornja Vukuvija & $2 \cdot 6$ \\
\hline 25 & 21 & 11 & Poljana & $0 \cdot 15$ & 4.5 & 07 & Bistarac D.G. & $2 \cdot 0$ \\
\hline 26 & 21 & 16 & Tinja Brezik & 0.47 & $6 \cdot 8$ & 07 & Podpeč & 0.88 \\
\hline 27 & 21 & 20 & Vasiljevći & 0.00 & 0.00 & 03 & Vasiljevći & 0.00 \\
\hline 28 & 22 & 02 & Vitez & 0.07 & 0.96 & 04 & Sadovaća etc. & 1.1 \\
\hline 29 & 22 & 04 & Guća Gora & 0.02 & $2 \cdot 2$ & 03 & Višnjevo & $10 \cdot 0$ \\
\hline 30 & 22 & 05 & Turbe & 0.00 & 0.92 & 11 & Varošluk & 0.4 \\
\hline 31 & 23 & 01 & Golubinja & 0.62 & $4 \cdot 0$ & 05 & Mestova-Ravna & 7.5 \\
\hline 32 & 23 & 02 & Careva Cuprija & 0.42 & 13.9 & 03 & Rijeka & $12 \cdot 2$ \\
\hline 33 & 24 & 09 & Nemila & 0.00 & 3.8 & 01 & Nemila & $4 \cdot 7$ \\
\hline 44 & 28 & 07 & Milići & 0.00 & $2 \cdot 3$ & 06 & Rajiči etc. & 0.60 \\
\hline 45 & 29 & 01 & Todorovc & 0.36 & 1.9 & 05 & Vejinac & 0.49 \\
\hline 46 & 29 & 03 & Mala Kladuša & 0.02 & $2 \cdot 7$ & 01 & Glavica & $4 \cdot 3$ \\
\hline 47 & 29 & 04 & Velika Kladuša & 0.08 & 3.9 & 07 & Kumarica & 7.9 \\
\hline 48 & 30 & - & - & 0.00 & $1 \cdot 1$ & 03 & Poklecani & $0 \cdot 28$ \\
\hline
\end{tabular}

aAdministrative division at the time of the ITS

The average seroreactor rate in the population examined at the ITS was 5.9 per cent. (Table II). The corresponding estimated rate which would have been obtained from the examination of a cluster of 250 persons in the selected villages in the present sample is 6.4 per cent., with an approximate 95 per cent. confidence interval ranging from $5 \cdot 2$ to $7 \cdot 6$ per cent. The sample is therefore considered to be reasonably representative of the population in this respect.

In each of the 48 sample villages, a population cluster comprising 250 persons was selected on a household basis by survey teams in the field. For this purpose up-to-date census lists were established for the entire village and a random sample was selected by means of a list of random numbers.

\section{Field procedures}

The field survey procedures included the use of household cards which were completed during the village census. An individual record card was prepared for each person in the selected cluster. For the retrospective study a special individual card was 


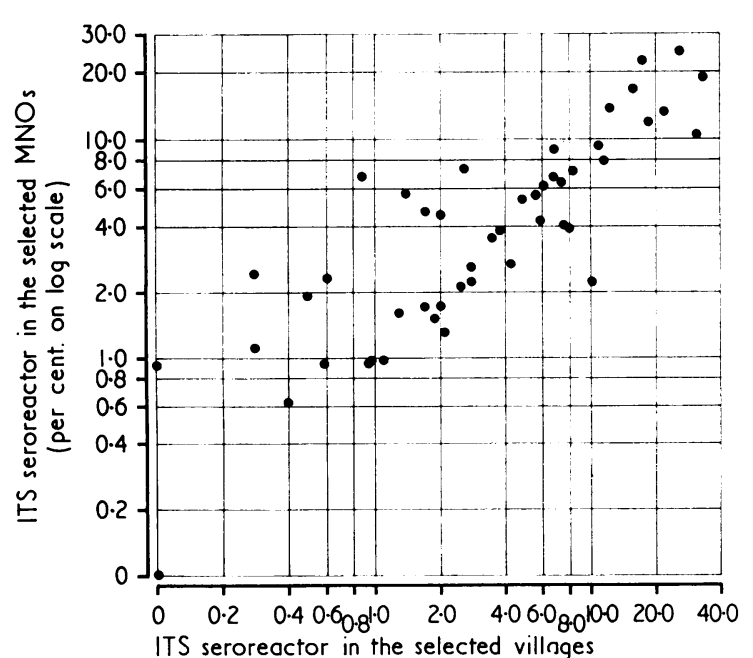

(per cent. on log scale)

FIG. 5 Correlation between the reactor rates at ITS in the selected villages and the corresponding MNOs

established for recording data on individuals whom personal, clinical, serological, and other information was available from the previous mass campaign in the central registry in Sarajevo. All persons selected in the clusters were checked against this register.

The field procedures comprised history taking, clinical inspection, venepuncture, and preparation of dried blood specimens (rondelles). Arrangements for optimal transport of specimens were made. Deep- frozen specimens were shipped to WHO reference centres and the collaborating laboratories, as specified in the Survey Design and Working Protocol (INT/ VDT/70.315).

The field procedures included, finally, provision of certain curative medical care for simple illnesses among the village populations.

\section{Laboratory procedures}

All sera were examined at the Sarajevo laboratory by the VDRL, Meinecke, and FTA tests. A subsample, representing all sera obtained in twelve out of 48 villages, was examined by the TPI test also. These sera were examined in the same tests at the WHO Reference Centre in Copenhagen. A special 'triple assay' or proficiency study of the TPI test results was organized between the Reference Centres in Copenhagen and Atlanta and the Sarajevo laboratory.

The deep-frozen serum aliquots in Sarajevo were also shipped in liquid nitrogen to several collaborating laboratories for immunological tests for various other conditions.

\section{Data processing}

All data were collected at WHO headquarters for collation and exploitation in co-operation with the Institute in Sarajevo, the WHO reference centres, and the collaborating laboratories.

\section{Results of the Study}

The results of the general seroepidemiological study carried out from 1968 to 1970 will be presented first,

TABLE V Coverage of the selected sample, according to age groups and sex

\begin{tabular}{|c|c|c|c|c|c|c|c|c|c|c|c|c|}
\hline \multirow{2}{*}{$\begin{array}{l}\text { Age } \\
\text { group } \\
\text { (yrs) }\end{array}$} & \multicolumn{4}{|l|}{ Male } & \multicolumn{4}{|l|}{ Female } & \multicolumn{4}{|c|}{ Both sexes } \\
\hline & Selected & Absent ${ }^{\mathrm{a}}$ & Examined & Per cent. & Selected & Absent $t^{\mathrm{a}}$ & Examined & Per cent. & Selected & Absent ${ }^{\mathrm{a}}$ & Examined & Per cent. \\
\hline $0-1$ & 231 & 154 & 77 & $33 \cdot 3$ & 241 & 170 & 71 & $29 \cdot 5$ & 472 & 324 & 148 & $31 \cdot 4$ \\
\hline $2-4$ & 527 & 106 & 421 & $79 \cdot 9$ & 515 & 105 & 410 & $79 \cdot 6$ & 1,042 & 211 & 831 & $79 \cdot 8$ \\
\hline $5-9$ & 965 & 94 & 871 & $90 \cdot 3$ & 897 & 75 & 822 & $91 \cdot 6$ & 1,862 & 169 & 1,693 & $90 \cdot 9$ \\
\hline $10-14$ & 927 & 87 & 840 & $90 \cdot 6$ & 860 & 83 & 777 & $90 \cdot 3$ & 1,787 & 170 & 1,617 & $90 \cdot 5$ \\
\hline $0-14$ & 2,650 & 441 & 2,209 & $83 \cdot 4$ & 2,513 & 433 & 2,080 & $82 \cdot 8$ & 5,163 & 874 & 4,289 & $83 \cdot 1$ \\
\hline $15-29$ & 1,263 & 392 & 871 & $69 \cdot 0$ & 1,504 & 184 & 1,320 & $87 \cdot 8$ & 2,767 & 576 & 2,191 & $79 \cdot 2$ \\
\hline $30-44$ & 1,054 & 434 & 620 & $58 \cdot 8$ & 1,212 & 140 & 1,072 & $88 \cdot 4$ & 2,266 & 574 & 1,692 & $74 \cdot 7$ \\
\hline $45-59$ & 537 & 143 & 394 & $73 \cdot 4$ & 650 & 92 & 558 & $85 \cdot 8$ & 1,187 & 235 & 952 & $80 \cdot 2$ \\
\hline $60+$ & 368 & 81 & 287 & $78 \cdot 0$ & 357 & 87 & 270 & $75 \cdot 6$ & 725 & 168 & 557 & $76 \cdot 8$ \\
\hline $15+$ & 3,222 & 1,050 & 2,172 & $67 \cdot 4$ & 3,723 & 503 & 3,220 & $86 \cdot 5$ & 6,945 & 1,553 & 5,392 & $77 \cdot 6$ \\
\hline Total & 5,872 & 1,491 & 4,381 & $74 \cdot 6$ & 6,236 & 936 & 5,300 & $85 \cdot 0$ & 12,108 & 2,427 & 9,681 & $80 \cdot 0$ \\
\hline
\end{tabular}

a Absent comprises selected persons who either did not present themselves or refused examination as well as individuals from whom no adequate serum sample could be obtained for serological examination 
to be followed by the results of the retrospective study based on the records from the mass campaign.

\section{General seroepidemiological study}

(i) Sampling performance

A total sample population of 12,108 persons was selected in 48 clusters. Table $\mathrm{V}$ shows the coverage of the selected sample according to age-groups and sex. The average coverage was 80 per cent. Most of the missed coverage was caused by failure to obtain sufficient blood for serological examination from the youngest children of both sexes, either because the parents refused to submit their children to bloodletting or because of failure of technique. A second cause was absence from the examination of adult men, many of whom worked at a considerable distance from their villages and, in many instances, came home late in the evening or during weekends only. Notwithstanding the 20 per cent. loss of coverage, the population sample remains sufficiently representative to allow conclusions to be drawn.

TABLE VI Seroreactor rates (Meinicke test) at ITS and as established in seroepidemiological evaluation study, according to sample village

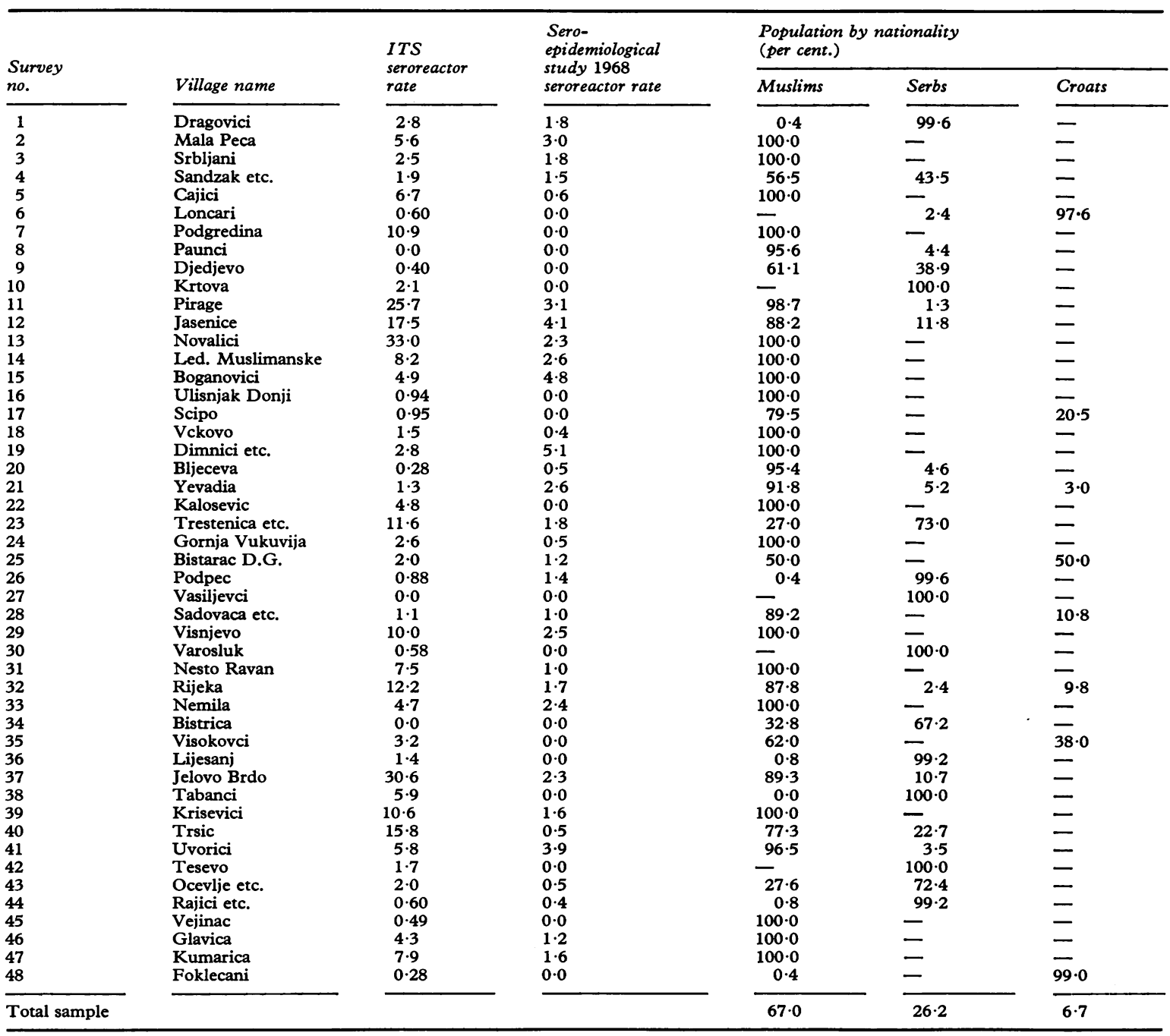


(ii) Results of serological testing in the Sarajevo laboratory

Table VI shows the average seroreactor rates at the ITS in the 48 sample villages, compared with the rates during the present seroepidemiological study, based on the Meinicke test, the only test used on both occasions. A considerable decrease is noted in all the sample villages except three. In many villages no seroreactors were found at all. The average initial rate at ITS was shown to be 5.94 per cent. (Table II). In the sample population examined in 1968 the average seroreactivity rate in the same test was 1.22 per cent. (Table VII) - a considerable decrease. The previous socioeconomic conditions of the Muslim ethnic group have been shown to have resulted in a higher prevalence of infection than in other groups and higher in females than in males. The seroreactor rates found in the evaluation study in 1968 were therefore broken down according to ethnic groups in Table VII. The reactor rate in the Muslim population was still higher than in the other groups, but in all groups the rates had decreased significantly.

It should be noted that the impact of the mass campaign coincided with an impressive improvement of the socioeconomic conditions throughout Yugoslavia after the war, and of the peasant Muslim population of Bosnia in particular. The mass campaign lasted from 1948 to 1955 . The children up to 15 years old examined in the evaluation study in 1968 were all born after the mass campaign and grew up in a period of rapid environmental improvement, e.g. industrialization, schooling, improvement of communications, intensive medical and social welfare activity, etc. Clinical lesions of endemic syphilis having disappeared from Bosnia, the investigation of seroreactivity in the children was therefore of utmost importance to evaluate the effect of the mass campaign. As the TPI test is the most specific indicator of past and-to some extent-recent treponemal infection, the TPI results will be discussed first. 2,358 sera were tested from a subsample of twelve villages which had a much higher rate of endemic syphilis than the average in the endemic area at the time of the mass campaign. The results (Table VIII) indicate the absence of TPI reactors in the youngest children (up to 5 years old). One TPI seroreactor (a boy aged 9 years) was found in the next age group of 5 to 9 years. The next older group of children, 10 to 14 years, showed no seroreactors. The adults, from 15 years onwards, showed an age-related increase in seroreactivity, the maximum being 13.3 per cent in the 45 to 59 -year age group.

The TPI test results differ from results of the FTA-200 and Meinicke tests (Table VIII), but there is considerable agreement with the VDRL rates in the different age groups. In view of the high specificity of the TPI test, the much higher seroreactivity rates obtained by FTA-200 testing suggest a high proportion of false reactive FTA-200 results. Table IX indicates that fifty out of 95 reactive FTA-200 results were non-reactive in the TPI test. The sensitivity of the FTA-200 test was also unsatisfactory when compared with the TPI test: only 45 (69 per cent.) of 65 TPI-reactive sera were found to be reactive in the FTA-200 test. On the other hand, the results of the VDRL test are closer to the TPI test results. The

TABLE VII Seroreactor rates in Meinicke and VDRL tests, according to nationality in two age groups (Sarajevo laboratory)

\begin{tabular}{|c|c|c|c|c|c|c|c|}
\hline \multirow{3}{*}{ Nationality } & \multirow{3}{*}{$\begin{array}{l}\text { Age group } \\
\text { (yrs) }\end{array}$} & \multicolumn{3}{|l|}{ Meinicke test } & \multicolumn{3}{|l|}{$V D R L$ test } \\
\hline & & \multirow[t]{2}{*}{ No. examined } & \multicolumn{2}{|c|}{ Reactive } & \multirow[t]{2}{*}{ No. examined } & \multicolumn{2}{|c|}{ Reactive } \\
\hline & & & No. & Per cent. & & No. & Per cent. \\
\hline \multirow[t]{2}{*}{ Muslims } & $\begin{array}{l}0-14 \\
15+\end{array}$ & $\begin{array}{l}2,715 \\
3,526\end{array}$ & $\begin{array}{r}4 \\
101\end{array}$ & $\begin{array}{l}0 \cdot 15 \\
2 \cdot 86\end{array}$ & $\begin{array}{l}2,714 \\
3,527\end{array}$ & $\begin{array}{r}4 \\
266\end{array}$ & $\begin{array}{l}0 \cdot 15 \\
7 \cdot 54\end{array}$ \\
\hline & Total & 6,241 & 105 & $1 \cdot 68$ & 6,241 & 270 & $4 \cdot 33$ \\
\hline \multirow[t]{2}{*}{ Serbs } & $\begin{array}{l}0-14 \\
15+\end{array}$ & $\begin{array}{l}1,013 \\
1,507\end{array}$ & $\begin{array}{l}1 \\
8\end{array}$ & $\begin{array}{l}0.10 \\
0.53\end{array}$ & $\begin{array}{l}1,013 \\
1,507\end{array}$ & $\begin{array}{r}0 \\
14\end{array}$ & $\begin{array}{l}0.00 \\
0.93\end{array}$ \\
\hline & Total & 2,520 & 9 & 0.36 & 2,520 & 14 & 0.56 \\
\hline \multirow[t]{2}{*}{ Croats } & $\begin{array}{l}0-14 \\
15+\end{array}$ & $\begin{array}{l}229 \\
335\end{array}$ & $\begin{array}{l}0 \\
0\end{array}$ & $\begin{array}{l}0.00 \\
0.00\end{array}$ & $\begin{array}{l}229 \\
334\end{array}$ & $\begin{array}{l}0 \\
6\end{array}$ & $\begin{array}{l}0 \cdot 00 \\
1 \cdot 80\end{array}$ \\
\hline & Total & 564 & 0 & 0.00 & 563 & 6 & $1 \cdot 07$ \\
\hline \multirow[t]{2}{*}{ Total } & $\begin{array}{l}0-14 \\
15+\end{array}$ & $\begin{array}{l}3,957 \\
5,368\end{array}$ & $\begin{array}{r}5 \\
109\end{array}$ & $\begin{array}{l}0.13 \\
2.03\end{array}$ & $\begin{array}{l}3,956 \\
5,368\end{array}$ & $\begin{array}{r}4 \\
286\end{array}$ & $\begin{array}{l}0 \cdot 10 \\
5 \cdot 33\end{array}$ \\
\hline & Total & 9,325 & 114 & $1 \cdot 22$ & 9,324 & 290 & $3 \cdot 11$ \\
\hline
\end{tabular}


TABLE VIII Test results in TPI, FTA-200, VDRL, and Meinicke tests, according to age (Sarajevo laboratory)

\begin{tabular}{|c|c|c|c|c|c|c|c|c|c|c|c|c|c|c|c|}
\hline \multirow[b]{2}{*}{$\begin{array}{l}\text { Age } \\
\text { group } \\
\text { (yrs) }\end{array}$} & \multicolumn{4}{|l|}{$T P I$} & \multicolumn{3}{|c|}{$F T A-200$} & \multicolumn{4}{|l|}{$V D R L$} & \multicolumn{4}{|c|}{ Meinicke } \\
\hline & Tested & \pm & + & $\begin{array}{l}\text { Total } \\
\text { reactive } \\
\text { per } \\
\text { cent. }\end{array}$ & Tested & + & $\begin{array}{l}\text { per } \\
\text { cent. }\end{array}$ & Tested & \pm & + & $\begin{array}{l}\text { Total } \\
\text { reactive } \\
\text { per } \\
\text { cent. }\end{array}$ & Tested & \pm & + & $\begin{array}{l}\text { Total } \\
\text { reactive } \\
\text { per } \\
\text { cent. }\end{array}$ \\
\hline $0-1$ & 8 & 0 & 0 & 0.0 & 30 & 0 & 0.0 & 30 & 0 & 0 & 0.0 & 30 & 0 & 0 & 0.0 \\
\hline $2-4$ & 183 & 0 & 0 & 0.0 & 669 & 4 & 0.6 & 670 & 1 & 1 & 0.3 & 670 & 2 & $\mathbf{0}$ & 0.3 \\
\hline $10-14$ & 386 & 0 & 0 & 0.0 & 1,603 & 24 & 1.5 & 1,604 & 2 & 0 & $0 \cdot 1$ & 1,605 & 2 & 0 & 0.1 \\
\hline $0-14$ & 1,035 & 1 & 0 & 0.1 & 3,952 & 33 & 0.8 & 3,956 & 3 & 1 & 0.1 & 3,957 & 5 & 0 & 0.1 \\
\hline $15-29$ & 573 & 1 & 2 & 0.5 & 2,178 & 36 & $1 \cdot 7$ & 2,184 & 8 & 7 & $0 \cdot 7$ & 2,184 & 8 & 4 & 0.5 \\
\hline $30-44$ & 409 & 4 & 14 & $4 \cdot 4$ & 1,681 & 111 & $6 \cdot 6$ & 1,682 & 35 & 28 & $3 \cdot 7$ & 1,682 & 20 & 5 & 1.5 \\
\hline Total & 2,358 & 28 & 38 & $2 \cdot 8$ & 9,312 & 427 & $4 \cdot 6$ & 9,324 & 181 & 109 & $3 \cdot 1$ & 9,325 & 84 & 30 & $1 \cdot 2$ \\
\hline
\end{tabular}

TABLE IX Comparison of TPI and FTA-200 results (Sarajevo laboratory)

\begin{tabular}{|c|c|c|c|c|}
\hline \multirow{2}{*}{$\begin{array}{l}F T A \\
\text { Sarajevo }\end{array}$} & \multicolumn{4}{|c|}{ TPI-Sarajevo } \\
\hline & - & \pm & + & Total \\
\hline- & 2,240 & 8 & 12 & 2,260 \\
\hline+ & 50 & 20 & 25 & 95 \\
\hline Total & 2,290 & 28 & 37 & 2,355 \\
\hline
\end{tabular}

Meinicke results in Sarajevo show much lower rates of reactivity than the other serological tests; it was included in the battery of tests used, as it had been used extensively during the previous mass campaign.

(iii) Serological results at the WHO Reference Laboratory, Copenhagen

Table X (overleaf, pp. 12 and 13) shows the results obtained in the treponemal antigen tests (TPI and FTA-200) and in the reagin tests (VDRL, Meinicke, Wassermann, and Kahn) in the Reference Laboratory. TPI-reactors were found in the age groups from 2 to 4 years onwards. The reactivity rates were low up to 10 to 14 years and thereafter increased with age. FTA-200 and VDRL rates are consistently higher in all age groups than the TPI rate.

(iv) Comparison of TPI and FTA-200 results at different laboratories

Comparison of specificity and sensitivity of the TPI and FTA-200 results between the two laboratories is shown in Tables XI and XII. Apparently the sensitivity of both tests was greater in the Reference Laboratory than in Sarajevo. To study the differences in the results with particular reference to the TPI test, a blind 'triple assay' was organized on the basis of a collection of selected sera comprising most of TABLE XI Comparison of TPI test results in Sarajevo and Copenhagen

\begin{tabular}{|c|c|c|c|c|}
\hline \multirow{2}{*}{$\begin{array}{l}\text { TPI } \\
\text { Copenhagen }\end{array}$} & \multicolumn{4}{|c|}{ TPI Sarajevo } \\
\hline & - & \pm & + & Total \\
\hline - & 2,142 & 17 & 16 & 2,175 \\
\hline \pm & 27 & 6 & 2 & 35 \\
\hline+ & 29 & 4 & 19 & 52 \\
\hline Total & 2,198 & 27 & 37 & 2,262 \\
\hline
\end{tabular}

TABLE XII Comparison of FTA-200 test results in Sarajevo and Copenhagen

\begin{tabular}{|c|c|c|c|}
\hline \multirow{2}{*}{$\begin{array}{l}F T A \\
\text { Copenhagen }\end{array}$} & \multicolumn{3}{|c|}{ FTA Sarajevo } \\
\hline & - & + & Total \\
\hline - & 2,042 & 28 & 2,070 \\
\hline+ & 143 & 68 & 211 \\
\hline Total & 2,185 & 96 & 2,281 \\
\hline
\end{tabular}

Co-negativity: $\quad 2,042 / 2,070=98.6$ per cent.

Co-positivity: $\quad 68 / 211=32 \cdot 2$ per cent.

Overall agreement: $2,110 / 2,281=92.5$ per cent. 
TABLE X Test results in TPI, FTA-200, VDRL, Meinicke tests, Wassermann reaction, and Kahn tests according tQ age

\begin{tabular}{|c|c|c|c|c|c|c|c|c|c|c|c|}
\hline \multirow[b]{2}{*}{$\begin{array}{l}\text { Age } \\
\text { group } \\
\text { (yrs.) }\end{array}$} & \multicolumn{4}{|l|}{$T P I$} & \multicolumn{3}{|c|}{$F T A-200$} & \multicolumn{3}{|l|}{$V D R L$} & $\overline{\bar{s}}$ \\
\hline & Tested & \pm & + & $\begin{array}{l}\text { Total } \\
\text { reactive } \\
\text { per cent. }\end{array}$ & Tested & + & Per cent. & Tested & \pm & + & $\begin{array}{l}\text { Thal } \\
\text { reactive } \\
\text { p\&ैं cent. }\end{array}$ \\
\hline $0-1$ & 6 & 0 & 0 & 0.0 & 6 & 0 & 0.0 & 6 & 1 & 0 & $\overrightarrow{16}$ \\
\hline $2-4$ & 148 & 1 & 2 & $2 \cdot 0$ & 150 & 5 & $3 \cdot 3$ & 146 & 8 & 0 & $\overrightarrow{55}$ \\
\hline 5-9 & 430 & 4 & 3 & $1 \cdot 6$ & 433 & 11 & $2 \cdot 5$ & 419 & 11 & 1 & क्ष9 \\
\hline $10-14$ & 381 & 3 & 3 & 1.6 & 381 & 19 & $5 \cdot 0$ & 369 & 13 & 0 & $\frac{395}{c 0}$ \\
\hline $0-14$ & 965 & 8 & 8 & $1 \cdot 7$ & 970 & 35 & $3 \cdot 6$ & 940 & 33 & 1 & 3.6 \\
\hline $15-29$ & 564 & 9 & 12 & $3 \cdot 7$ & 569 & 38 & $6 \cdot 7$ & 552 & 24 & 4 & 51 \\
\hline $30-44$ & 409 & 5 & 13 & $4 \cdot 4$ & 408 & 62 & $15 \cdot 2$ & 404 & 31 & 23 & $13 \cdot 4$ \\
\hline $45-59$ & 214 & 9 & 12 & $9 \cdot 8$ & 217 & 39 & $18 \cdot 0$ & 208 & 26 & 27 & 250 \\
\hline $60+$ & 122 & 6 & 8 & 11.5 & 122 & 38 & $31 \cdot 1$ & 118 & 14 & 22 & उक्स్5 \\
\hline $15+$ & 1,309 & 29 & 45 & $5 \cdot 7$ & 1,316 & 177 & $13 \cdot 4$ & 1,282 & 95 & 76 & $13 \cdot 3$ \\
\hline Total & 2,274 & 37 & 53 & 4.0 & 2,286 & 212 & $9 \cdot 3$ & 2,222 & 128 & 77 & क्षे \\
\hline
\end{tabular}

those found reactive in either Copenhagen or in Sarajevo (or both). The triple assay concerned 293 coded serum specimens and testing was carried out in the Sarajevo and Copenhagen laboratories, as well as at the VDRL laboratory, USPHS, Atlanta.

\section{(v) Reproducibility of the TPI test}

The reproducibility of the TPI test has frequently been studied, especially during the first years after its introduction at the WHO International Treponematoses Laboratory Center, Johns Hopkins University, in 1949. Interlaboratory investigations undertaken through WHO were unable to verify the limits within which the test could be reproduced in different laboratories. In the context of the present study of 'disappearing' endemic treponematoses in Bosnia, it was considered necessary to examine these aspects further. Moreover, proficiency testing is being undertaken in a number of leading centres, the results of which will be published in the near future. The data obtained in the triple assay regarding sera from the study in Bosnia are voluminous and will require extensive statistical analysis, the results of which will be published separately. A preliminary study has, nevertheless, shown that some inter-laboratory variation occurs. Intra-laboratory variation in the results of testing of paired, coded, sera was also noted. Both the inter- and the intra-laboratory variations occurred mainly with weakly reactive sera which are sometimes diagnosed as non-reactive and sometimes as reactive. The testing of clearly reactive or nonreactive sera rarely gives rise to discrepancies. Before extensive analysis of carefully designed proficiency testing becomes available, it is recommended that some caution should be exercised in the interpretation of the results of TPI testing. For the vast majority of TPI tests carried out, unequivocal conclusions are justified, but in a minority of cases it appears prudent not to consider the TPI test results as the final and absolute criterion of past or present treponemal infection, but to take all other clinical and serological evidence into account.

Preliminary analysis of the triple assay data showed that intra-laboratory variation in results of blind testing of paired sera did not occur in the Sarajevo laboratory. Furthermore, it was shown that a remarkable consistency existed in the Sarajevo laboratory results of TPI tests of coded sera obtained from the same individual at different periods. It is therefore considered appropriate to use the results of the TPI testing in the Sarajevo laboratory to evaluate the outcome of the mass campaign, especially as almost all of the Sarajevo results were confirmed by the findings in the Reference Laboratories. Discrepancies between test results in children born after the mass campaign were extremely rare, and taking into account the nonreactivity of these sera in almost all the other serological tests used these should be regarded as open to varying interpretations.

The analysis of the age-specific TPI-reactivity rates (Table VIII) brought to light only one TPIreactive individual (a 9-year-old boy) among the children under 14 years of age, that is among those born after the completion of the mass campaign in 1953. For the last 8 years no child was shown to have 
(Copenhagen laboratory)

\begin{tabular}{|c|c|c|c|c|c|c|c|c|c|}
\hline \multicolumn{4}{|c|}{ 'einicke } & \multicolumn{3}{|c|}{ Wassermann } & \multicolumn{3}{|l|}{ Kahn } \\
\hline ted & \pm & + & $\begin{array}{l}\text { Total } \\
\text { reactive } \\
\text { per cent. }\end{array}$ & Tested & + & $\begin{array}{l}\text { Total } \\
\text { reactive } \\
\text { per cent. }\end{array}$ & Tested & + & $\begin{array}{l}\text { Total } \\
\text { reactive } \\
\text { per cent. }\end{array}$ \\
\hline 6 & 1 & 0 & $16 \cdot 7$ & 5 & 0 & 0.0 & 2 & 0 & 0.0 \\
\hline 123 & 1 & 0 & $0 \cdot 8$ & 143 & 0 & $0 \cdot 0$ & 120 & 3 & 2.5 \\
\hline 359 & 12 & 0 & $3 \cdot 3$ & 428 & 1 & $0 \cdot 2$ & 405 & 2 & 0.5 \\
\hline 324 & 17 & 0 & $5 \cdot 2$ & 374 & 0 & 0.0 & 366 & 5 & $1 \cdot 4$ \\
\hline 812 & 31 & 0 & $3 \cdot 8$ & 950 & 1 & $0 \cdot 1$ & 893 & 10 & $1 \cdot 1$ \\
\hline 478 & 24 & 1 & $5 \cdot 2$ & 568 & 0 & 0.0 & 554 & 8 & $1 \cdot 4$ \\
\hline 343 & 15 & 2 & $5 \cdot 0$ & 403 & 2 & 0.5 & 390 & 3 & $0 \cdot 8$ \\
\hline 182 & 18 & 0 & 9.9 & 212 & 1 & 0.5 & 201 & 5 & $2 \cdot 5$ \\
\hline 104 & 16 & 1 & $16 \cdot 3$ & 119 & 1 & $0 \cdot 8$ & 106 & 4 & $3 \cdot 8$ \\
\hline 1,107 & 73 & 4 & $7 \cdot 0$ & 1,302 & 4 & 0.3 & 1,251 & 20 & 1.6 \\
\hline 1,919 & 104 & 4 & $5 \cdot 6$ & 2,252 & 5 & 0.2 & 2,144 & 30 & $1 \cdot 4$ \\
\hline
\end{tabular}

been infected. Together with the absence of any active clinical cases, this sero-negativity permits us to conclude that complete eradication, according to the criteria of the WHO Expert Committee of 1961, was attained.

\section{Retrospective seroepidemiological study}

During the mass campaign against endemic treponematosis in Bosnia, individual records were established of all the findings during the ITS and the consecutive RSs. The preservation of the records concerning individuals examined at that time made it possible to assess the outcome of the mass campaign by comparing the findings in the present seroepidemiological study with those concerning the same individuals at the time of the mass campaign (Tables XIV to XXIV).
The children born after the campaign and examined in $1968 \mathrm{had}$, of course, no previous records. This group accounts for 4,289 individuals out of a total of 9,681 examined in the seroepidemiological evaluation study (Table V). On the other hand, many individuals examined in the mass campaign (1948-55) died before 1968, and their previous records could not be used for comparison with the 1968 data. In the years which have elapsed since the beginning of the mass campaign, from 15 to 20 per cent. of the population have thus disappeared. Therefore, of 5,392 persons over 15 years of age examined in 1968, mass campaign records could be expected to be available for approximately only 80 to 85 per cent. $(4,000$ to 4,500 individuals). In fact, ITS records concerning 2,402 persons were retrieved from the Central Registry at Sarajevo, representing 55 to 60 per cent. of the highest possible number. Regarding

TABLE XIII Comparison of the distribution by sex and nationality of $(A)$ the persons for whom ITS records were retrieved, and $(B)$ the total sample population examined in 1968

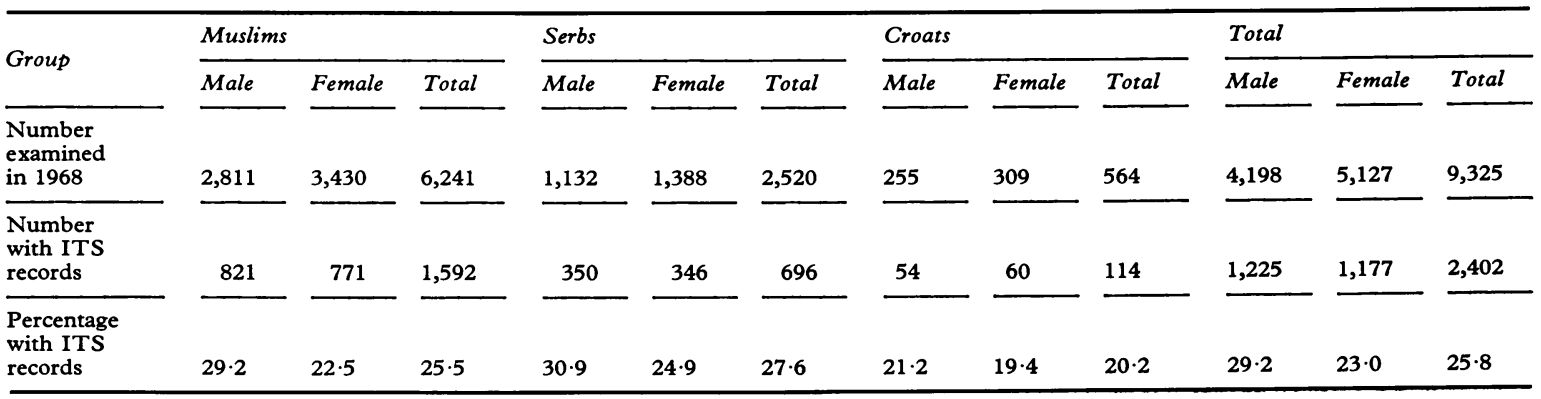


the 1,500 to 2,000 individuals for whom no previous records could be retrieved, it should be noted thatin the course of the last 20 years-a great number of families and individuals moved to other villages and towns (urbanization) and could not be located in 1968 in the 48 sample villages where they had lived at the time of the mass campaign.

The examination of the background data on 2,402 individuals permits retrospective evaluation of the mass campaign from another angle than that of the general assessment of the seroepidemiological findings as presented above.

Table XIII shows that the distribution of individuals according to sex and nationality was approximately the same in the retrieved ITS records as in the sample examined during the seroepidemiological study. It may, therefore, be assumed that the 2,402

TABLE XIV Persons examined at ITS and subsequent re-surveys of the mass campaign during the seroepidemiological study (1968)

\begin{tabular}{|c|c|c|c|c|c|}
\hline $\begin{array}{l}\text { Calendar } \\
\text { year }\end{array}$ & $\begin{array}{l}\text { Examined } \\
\text { at ITS }\end{array}$ & 1st $R S$ & $2 n d R S$ & $3 r d R S$ & $4 t h R S$ \\
\hline 1948 & 206 & - & - & - & - \\
\hline 1949 & 538 & - & - & - & - \\
\hline 1950 & 300 & 103 & - & - & - \\
\hline 1951 & 519 & 339 & 103 & - & - \\
\hline 1952 & 347 & 388 & 64 & - & - \\
\hline 1953 & 347 & 153 & 412 & 103 & - \\
\hline 1954 & 98 & 209 & 49 & - & - \\
\hline 1955 & - & - & - & - & - \\
\hline 1956 & 47 & - & - & - & - \\
\hline 1957 & - & - & - & - & - \\
\hline 1958 & - & - & - & - & - \\
\hline 1959 & - & - & - & - & - \\
\hline 1960 & 一 & - & - & - & - \\
\hline 1961 & - & 一 & - & - & 103 \\
\hline Total & 2,402 & 1,192 & 628 & 103 & 103 \\
\hline
\end{tabular}

mass campaign records available represent an acceptable sample of the Bosnian population.

The numbers of individuals examined at subsequent RSs after ITS decreased rapidly at each successive RS (Table XIV). Table XV shows that at ITS the policy was treatment of all overt active and inactive clinical cases and latent cases (seroreactors). The number of contacts treated was limited-only 22 out of a total of 2,370 persons $(0.93$ per cent.). At ITS seven cases of infectious lesions were found in 2,370 persons examined (ITS data were retrieved for 32 persons who were younger than 15 years in 1968 but none had a record of clinical or serological findings and they are therefore not considered here). This is 0.3 per cent. as compared to an average of 0.44 per cent. in the whole population observed at ITS (Table IIa). The much higher prevalence of clinical and serological endemic syphilis in the Muslim group than in the other groups is also shown in Table XV.

Table XVI shows a characteristic hypoendemic area with benign infectious lesions in some age groups. The infectious lesions in persons concerning whom ITS data were available were found mainly among the adolescent and adult groups. The same appears to apply to non-infectious and inactive lesions, as far as the small numbers allow conclusions. The majority of seroreactors were also found in the higher age groups.

The clinical cases shown in Table XVII were found in eight villages only. At ITS five infectious cases were detected in Village 31 and two in Village 47, where also one active non-infectious case was found. The six inactive cases were found in Villages 1 , $3,11,32,37$, and 46.

TABLE XV Clinical and serological findings at ITS of 2,370 persons aged 15 years or older treated as case or contact or not treated at ITS, according to nationality

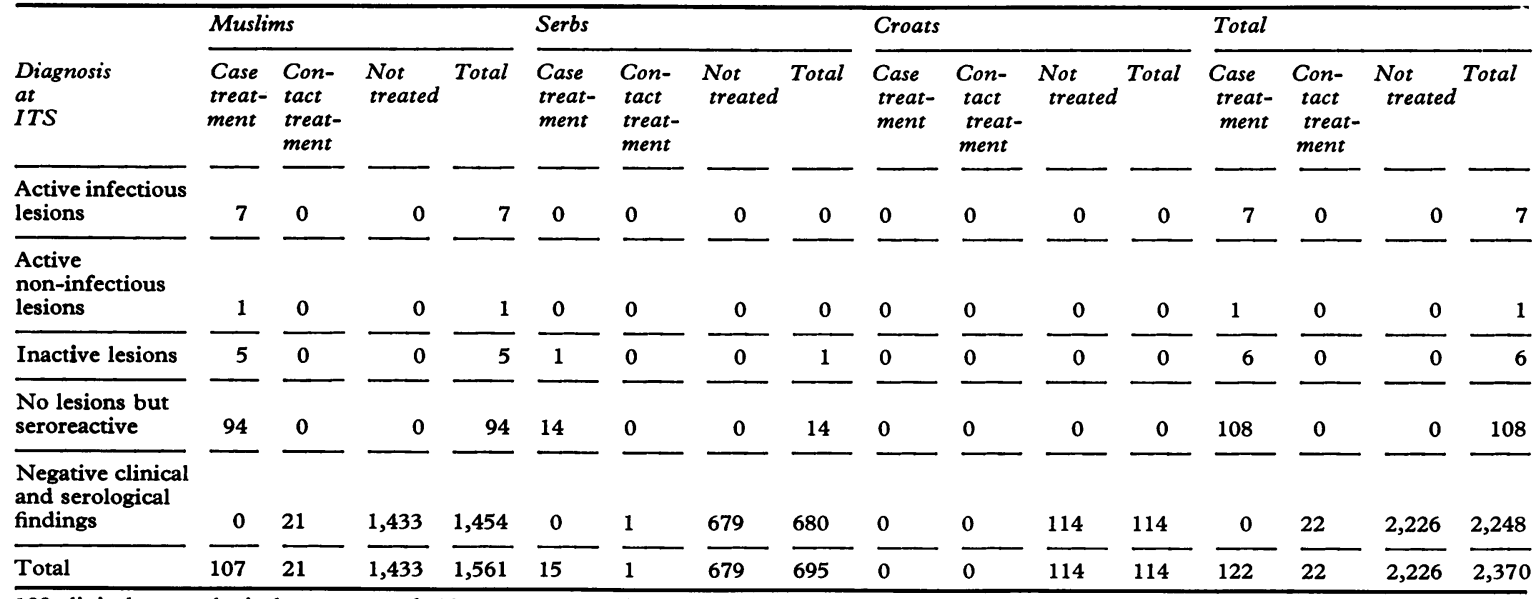

122 clinical or serological cases treated, 22 contacts treated, 2,326 persons untreated 
TABLE XVI Distribution of 122 persons treated at ITS as clinical or serological cases, according to age at ITS

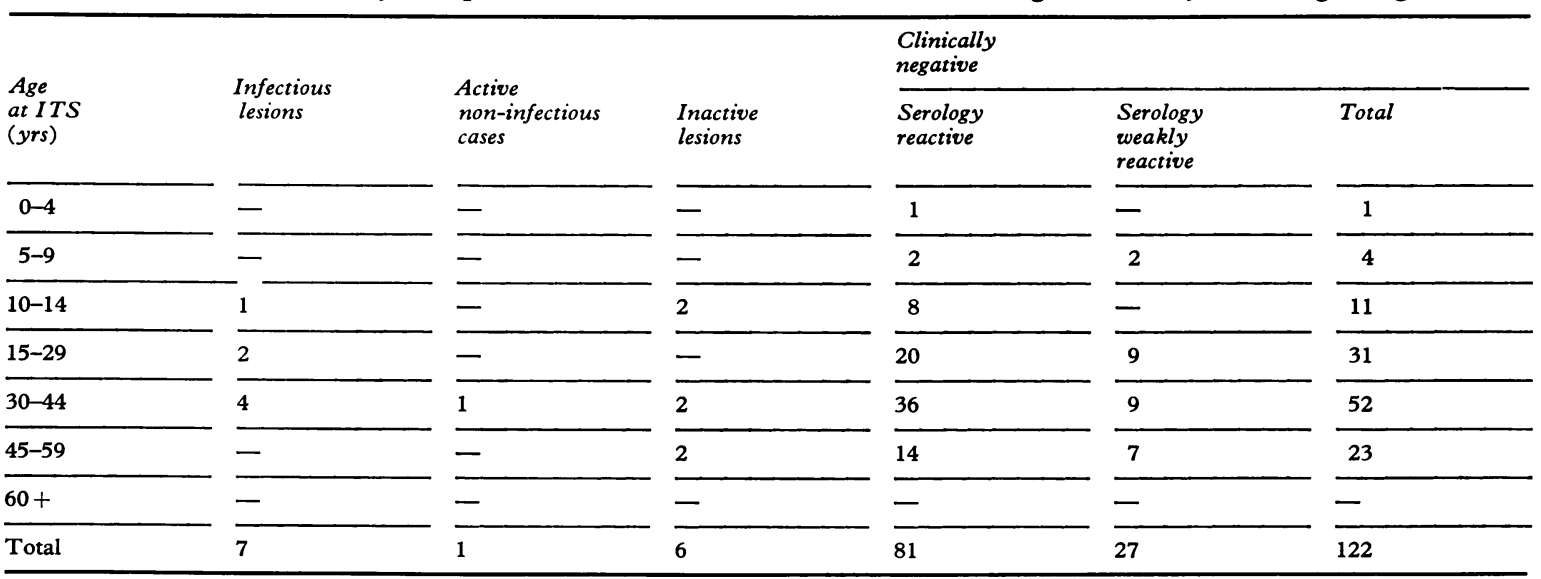

${ }^{\star}$ Meinicke test

During the first RS, one active infectious case was recorded in Village 12, together with one active but non-infectious case. No further clinical cases are to be found in the available records of the mass cam- paign. It is remarkable that the villages where the seven ITS infectious cases were found did not belong to the most heavily infected villages (Table VI).

TABLE XVII PAM treatment schedules used at ITS in the 122 active cases

\begin{tabular}{|c|c|c|c|c|c|c|c|c|c|c|c|c|}
\hline $\begin{array}{l}\text { Number } \\
\text { of } \\
\text { injections }\end{array}$ & \multicolumn{11}{|c|}{ Total dosage of PAM $(\mathrm{ml} .)^{\mathrm{a}}$} & $\begin{array}{l}\text { Total } \\
\text { cases } \\
\text { treated }\end{array}$ \\
\hline 1 & 1 & - & 2 & - & 1 & - & 11 & 一 & - & - & - & 15 \\
\hline 2 & 一 & - & 3 & - & 2 & - & 22 & - & - & - & - & 27 \\
\hline 3 & 一 & - & 一 & 一 & - & - & 20 & - & - & - & - & 20 \\
\hline 5 & - & - & - & - & 1 & 一 & 1 & - & 一 & 一 & - & 2 \\
\hline 6 & - & 一 & 一 & 一 & 0 & 一 & 11 & - & 1 & 一 & - & 12 \\
\hline 7 & - & - & - & - & 1 & - & 0 & - & 43 & - & - & 44 \\
\hline Total & 1 & 0 & 5 & 0 & 6 & 0 & 65 & 0 & 44 & 0 & 1 & 122 \\
\hline
\end{tabular}

a ml. $=0.3 \mathrm{~m} . \mathrm{u}$.

Duration of treatment: 69 cases treated in 1 wk; 46 cases treated in 2 wks; 7 cases treated in 3 wks

TABLE XVII Treatment at initial survey (ITS) and at subsequent re-surveys (RS) of persons for whom records from mass campaign were available

Decision

for treatment

Case

(clinical or

serological)

Contact

No treatment

Total

ITS

Number Per cent.
1 st $R S$

Number Percent. 2nd $R S$

Number Percent. Number Percent. 4th $R S$

Number Per cent. 
Table XVII gives the dosage schedule of longacting penicillin (PAM) used for case treatment: the great majority of cases received 12 or $14 \mathrm{ml}$. (3.6 to 4.2 m.u.) in a varying number of injections, usually over 1 to 2 weeks. In only seven cases did the course of treatment last 3 weeks. Table XVIII shows that the rate of cases treated decreased during subsequent surveys and that contact treatment, already limited at ITS, was applied even less frequently during the RSs.

The results of serological testing at ITS and subsequent RSs did not show an impressive decrease of reactor rate as the mass campaign progressed (Table XIX). This should be seen in the light of the observation that in hypoendemic areas, like Bosnia, initially low reactor rates do not drop dramatically, as in hyperendemic areas. Also, the careful selection of people to be examined at RSs (which resulted in rapidly decreasing population coverage on consecutive occasions) increased the relative importance of reactors at later RSs, which made it seem that there was an increase in the number of reactors. More revealing are the results of serological testing in consecutive RSs of clinical and serological cases detected at ITS (Table XX). It is noted that the reactor rates decreased rapidly after treatment during ITS, as shown by the test results at the first and second RSs. (The apparent increase in seroreactivity in later RSs is due to an increased relative importance of reactors in the selective and continuously decreasing number of tests carried out.) The effectiveness of the penicillin treatment is thus borne out and the clinical rate at ITS of 0.3 per cent. decreased to 0.07 per cent. at the first RS and to nil at the second RS.

The results of the Meinicke test in 1968 in the same 122 individuals treated as cases during ITS are shown in Table XXI. The majority of reactors at ITS were found to be non-reactive in 1968 (64 out of 94). Only six ( 4.9 per cent.) were still reactive, the remainder being weakly reactive. Of those weakly reactive at ITS, the majority were non-reactive in 1968. Two were found to be reactive, which may be

TABLE XXI Comparison of results of Meinicke tests during ITS and during seroepidemiological study in 122 persons who had been treated as clinical or serological cases at ITS

\begin{tabular}{|c|c|c|c|c|c|}
\hline \multirow{2}{*}{$\begin{array}{l}\text { Meinicke } \\
\text { test } \\
\text { ITS }\end{array}$} & \multicolumn{5}{|c|}{ Meinicke test, 1968} \\
\hline & + & \pm & - & Unknown & Total \\
\hline+ & 6 & 24 & 64 & 1 & 95 \\
\hline \pm & 2 & 2 & 17 & 1 & 22 \\
\hline- & 0 & 0 & 4 & 0 & 4 \\
\hline Not done & 0 & 0 & 1 & 0 & 1 \\
\hline Total & 8 & 26 & 86 & 2 & 122 \\
\hline
\end{tabular}

TABLE XIX Results of Meinicke test at ITS and subsequent re-surveys

\begin{tabular}{|c|c|c|c|c|c|c|c|c|c|c|}
\hline \multirow{2}{*}{$\begin{array}{l}\text { Meinicke } \\
\text { test } \\
\text { results }\end{array}$} & \multicolumn{2}{|l|}{$I T S$} & \multicolumn{2}{|l|}{ 1st $R S$} & \multicolumn{2}{|l|}{ 2nd $R S$} & \multicolumn{2}{|l|}{$3 r d R S$} & \multicolumn{2}{|l|}{ 4th RS } \\
\hline & Number & Per cent. & Number & Per cent. & Number & Per cent. & Number & Per cent. & Number & Per cent. \\
\hline+ & 96 & $4 \cdot 7$ & 19 & $2 \cdot 1$ & 10 & $1 \cdot 8$ & 2 & $3 \cdot 5$ & 4 & $4 \cdot 3$ \\
\hline \pm & 40 & $1 \cdot 9$ & 28 & $3 \cdot 1$ & 15 & $2 \cdot 8$ & 1 & $1 \cdot 8$ & 8 & $8 \cdot 5$ \\
\hline- & 1,921 & $93 \cdot 4$ & 846 & $94 \cdot 7$ & 517 & $95 \cdot 4$ & 54 & $94 \cdot 7$ & 82 & $87 \cdot 2$ \\
\hline Total & 2,057 & 100 & 893 & 100 & 542 & 100 & 57 & 100 & 94 & 100 \\
\hline
\end{tabular}

TABLE XX Meinicke results at ITS and subsequent re-surveys of 122 clinical cases or latent cases found and treated at ITS

\begin{tabular}{|c|c|c|c|c|c|c|c|c|c|c|}
\hline \multirow{2}{*}{$\begin{array}{l}\text { Meinicke } \\
\text { test } \\
\text { results }\end{array}$} & \multicolumn{2}{|l|}{$I T S$} & \multicolumn{2}{|l|}{1 st $R S$} & \multicolumn{2}{|l|}{$2 n d R S$} & \multicolumn{2}{|l|}{$3 r d R S$} & \multicolumn{2}{|l|}{$4 t h R S$} \\
\hline & Number & Per cent. & Number & Per cent. & Number & Per cent. & Number & Per cent. & Number & Per cent. \\
\hline Positive & 95 & $78 \cdot 5$ & 12 & $15 \cdot 4$ & 8 & $12 \cdot 7$ & 1 & $16 \cdot 7$ & 3 & 50 \\
\hline Weakly positive & 22 & $18 \cdot 2$ & 14 & $18 \cdot 0$ & 9 & $14 \cdot 3$ & 1 & $16 \cdot 7$ & 2 & $33 \cdot 3$ \\
\hline Negative & 4 & $3 \cdot 3$ & 52 & $66 \cdot 7$ & 46 & $73 \cdot 0$ & 4 & $66 \cdot 6$ & 1 & $16 \cdot 7$ \\
\hline Examined & 121 & 100 & 78 & 100 & 63 & 100 & 6 & 100 & 6 & 100 \\
\hline Not done & 1 & & 44 & & 59 & & 116 & & 116 & \\
\hline Total & 122 & & 122 & & 122 & & 122 & & 122 & \\
\hline
\end{tabular}


explained by differences in test techniques so many years later. The individuals who remained reactive or weakly reactive up to 1968 , all adequately treated at ITS and without signs of clinical lesions, must be considered to have residual antibody. In four persons who were seronegative both at ITS and in 1968, the diagnosis at ITS was not precisely stated.

Table XXII shows the findings in the Meinicke test of persons left untreated at ITS. Out of 1,897 individuals tested, five were reactive in 1968 and nineteen weakly reactive. Among these 24 reactors, one only was weakly reactive at ITS. Differences, such as antigens used, sensitivity of test, and technique used some 20 years after ITS, may explain this observation, in the absence of recognized active clinical cases of endemic syphilis in Bosnia since 1959.

TABLE XXII Results of Meinicke testing during ITS and seroepidemiological study of 1,897 persons who were not treated at ITS

\begin{tabular}{|c|c|c|c|c|}
\hline \multirow{2}{*}{$\begin{array}{l}\text { Meinicke } \\
\text { test } \\
\text { ITS }\end{array}$} & \multicolumn{4}{|c|}{ Meinicke test, 1968} \\
\hline & + & \pm & - & Total \\
\hline+ & 0 & 0 & 1 & 1 \\
\hline \pm & 1 & 0 & 17 & 18 \\
\hline- & 4 & 19 & 1,855 & 1,878 \\
\hline Total & 5 & 19 & 1,873 & 1,897 \\
\hline
\end{tabular}

TABLE XXIII Meinicke results (1968) in 120 clinical or serological cases found at ITS, according to age

\begin{tabular}{|c|c|c|c|c|c|}
\hline \multirow[b]{2}{*}{$\begin{array}{l}\text { Age group } \\
\text { (yrs) }\end{array}$} & \multicolumn{4}{|c|}{ Meinicke test, 1968} & \multirow[b]{2}{*}{$\begin{array}{l}\text { Per cent } \\
\text { reactive }\end{array}$} \\
\hline & $\begin{array}{l}\text { No. } \\
\text { tested }\end{array}$ & \pm & + & - & \\
\hline $\begin{array}{l}15-29 \\
30-44 \\
45-59 \\
60+\end{array}$ & $\begin{array}{r}8 \\
30 \\
53 \\
29\end{array}$ & $\begin{array}{r}1 \\
7 \\
10 \\
8\end{array}$ & $\begin{array}{l}0 \\
1 \\
2 \\
5\end{array}$ & $\begin{array}{r}7 \\
22 \\
41 \\
16\end{array}$ & $\begin{array}{l}12 \cdot 5 \\
26 \cdot 7 \\
22 \cdot 6 \\
44 \cdot 8\end{array}$ \\
\hline Total & 120 & 26 & 8 & 86 & $28 \cdot 3$ \\
\hline
\end{tabular}

Table XXIII shows the distribution of the 1968 Meinicke test results of 120 cases found at ITS, according to age. As would be expected, the seroreactor rates increased with age. The oldest persons had infections of much longer duration than the younger individuals when they received treatment at ITS, and serofastness increases with duration of infection when treatment is initiated.

Table XXIV shows the TPI test results (1968) in persons for whom ITS data were available. It is recalled that a subsample of 25 per cent. of all the sera collected during the sero-epidemiological study was tested by TPI. Tests were performed for 690 persons out of the total of 2,402 for whom ITS data were available (28.7 per cent.). The TPI reactivity rate of the group which received case treatment at ITS was 54.4 per cent. (40.4 per cent. reactive, 14.0 per cent. weakly reactive). No person who had received contact treatment was found to be TPIreactive. In the group which had not received treatment at ITS, only 3.6 per cent. were found to be TPI-reactive ( 1.5 per cent. reactive and 2.1 per cent. weakly reactive). Furthermore, TPI testing was carried out in 1968 in 1,668 persons for whom no ITS records were then available. Of these 1,668 tests, six were reactive $(0.4$ per cent.) and seven weakly reactive $(0.4$ per cent.), the remaining 1,655 all being non-reactive ( 99.2 per cent.).

It is striking that the majority of the TPI-reactors belonged to the group which had been diagnosed and treated at ITS, although the group-represented only 5 per cent. of the population examined (122 out of 2,402). Persistence of immobilizing antibodies, even 15 to 20 years after adequate treatment, is found in all treponemal infections of some duration. The very few of TPI-reactors found in untreated persons and in the remainder of the population in Bosnia should probably be attributed to infections which had regressed before ITS-either spontaneously or as a result of treatment-and which already had become non-reactive in the Meinicke test. It is also possible

TABLE XXIV TPI results (1968) in 690 persons regarding whom ITS records were available, according to decision for treatment

\begin{tabular}{|c|c|c|c|c|c|c|c|c|}
\hline \multicolumn{2}{|l|}{ ITS treatment } & \multirow{2}{*}{$\begin{array}{l}\text { Examined } \\
\text { in TPI } \\
(1968)\end{array}$} & \multicolumn{6}{|c|}{ TPI results } \\
\hline Decision & Number & & Number & Per cent. & Number & Per cent. & Number & Per cent \\
\hline $\begin{array}{l}\text { Case } \\
\text { treatment }\end{array}$ & 122 & 57 & 23 & $40 \cdot 4$ & 8 & $14 \cdot 0$ & 26 & $45 \cdot 6$ \\
\hline $\begin{array}{l}\text { Contact } \\
\text { treatment }\end{array}$ & 22 & 18 & 0 & 0 & 0 & 0 & 18 & 100 \\
\hline Total & 2,402 & 690 & 32 & $4 \cdot 6$ & 21 & $3 \cdot 0$ & 637 & $92 \cdot 3$ \\
\hline
\end{tabular}


that latent infections which had remained undetected at ITS because of the low sensitivity of the Meinicke test were brought to light only by TPI testing 15 to 20 years later.

\section{Special clinical and laboratory study of TPI- reactors}

In order to define possible neurological, cardiovascular, ophthalmological, or other late complications of endemic syphilis in persons who were found to be TPI-reactive in the evaluation study in 1968, special examinations on such TPI-reactors were carried out in the Institute of Dermato-Venereology at Sarajevo. Of the 66 persons found to be reactive by TPI testing in 1968 in the Sarajevo laboratory, 35 agreed to visit Sarajevo for full examination. All were subjected to a complete cardiovascular, ophthalmological, and neurological examination, including lumbar puncture. Of the 35 , twenty had records of adequate treatment with long-acting penicillin at the time of the mass campaign. In these twenty cases, no late complications could reasonably be expected to occur (even if untreated endemic syphilis might have given rise to such complications). As expected, no signs of neurological, cardiovascular, or ophthalmological disturbances which could be ascribed to syphilitic involvement of these organs were found. Of the other fifteen, it was established that eight had not been treated at ITS because no clinical or serological signs of endemic syphilis had been found at that time. Nevertheless, they were found to be TPI-reactive in 1968. For the other seven, no records from the mass campaign could be retrieved, so that it was not known whether they had been treated or not. No unequivocal signs of systemic involvement of the internal organs were found in these fifteen cases. A few showed nonspecific neurological or ophthalmological abnormalities, but in the presence of perfectly normal cerebrospinal fluid these could not be accepted as evidence of systemic involvement by treponemal disease.

In order to investigate the presence of spiral organisms, examination of the aqueous humour and cerebrospinal fluid was undertaken in most of this group of 35 TPI-reactors. Some darkfield findings and positive immunofluorescent staining tests showed the presence of such organisms in some of the TPIreactive individuals, but infectivity tests were negative.

\section{Summary and conclusions}

An analysis of data collected in a seroepidemiological study of endemic non-venereal syphilis in Bosnia in 1968 compared with the findings during a previous mass campaign and available post-campaign surveillance data led to the conclusion that transmission of endemic syphilis was completely interrupted by the mass campaign. The latter was carried out against a background of rapid socioeconomic change in the affected population, along with the creation of modern health services to cover the entire population of the Republic of Bosnia-Herzegovina.

Analysis of the background data shows that this excellent result was brought about by intensive treatment of all cases detected through systematic clinical and serological screening of the affected population and of contacts exposed to infectious family members of the initial treatment survey and the re-surveys. Re-surveys during the post-campaign surveillance of the disease covered decreasing numbers of persons and were mainly directed towards high prevalence foci located at preceding surveys. The findings by the TPI test used in the seroepidemiological study in 1968 to 1970 indicate that the diagnostic procedures used during the mass campaign were adequate.

In the introduction to the present report, two essential public health questions were raised in relation to endemic syphilis, notably: 'Can early infectious clinical disease actually be eliminated' and 'Can transmission of infection be interrupted through the wide application of a specific drug, utilized in accordance with the epidemiological characteristics of the disease?'

The present study shows that early infectious disease CAN be eliminated and that the transmission of treponemal infection CAN be interrupted by a vigorous and carefully-conducted mass campaign, supported by the organization of an efficient health service with concomitant improvement in socioeconomic conditions, as was the case in Bosnia-Herzegovina.

\section{References}

Buxton, P. A. (1928) 'Researches in Polynesia and Melanesia', Parts V-VII, p. 85. London School of Hygiene and Tropical Medicine

Clark, E. G. (1950) WHO unpublished document INT/VD/36

Edmundson, W. F., Lopez Rico, A., and Olansky, S. (1953) Amer. F. Syph., 37, 221

GLüCK, L. (1888) Wien. med. Presse, 29, 993

GrIN, E. I. (1937) Socij.-med. Pregl., 7-9, 259

- (1953) 'Epidemiology and Control of Endemic Syphilis', Wld Hlth Org. Monogr. Ser. No. 11

- (1960) 'Proc. 11th Int. Congr. Derm. 1957', vol. 3, p. 914. Acta derm.-venereol. (Stockh).

- (1961) Narod. Zdrav., 17, 150

Guthe, T., and Luger, A. (1966) Derm. int. (Philad.), 5, 179

HaRding, R. D. (1949) Trans. roy. Soc. trop. Med. Hyg., 42, 347 
Kogoj, F., and Vuletic, A. (1939) In 'Endemijski Sifilis u Bosni', p. 205. Naklada Skole Narodnog Zdravlja u Zagrebu, Zagreb

LAMBert, S. M. (1936) f. trop. Med. Hyg., 39, 41

Levitan, S., Rodriguez, C., Jacobs, J. C., Petrus, E., and Durand, J. B. (1953) In 'I int. Symp. on Yaws Control', Wld Hlth Org. Monogr. Ser., No. 15, pp. 55-75

World Health Organization (1953) Expert Committee on Venereal Infections and Treponematoses, Fourth Report. Wld Hlth Org. tech. Rep. Ser. No. 63 - - (1960) Idem, Fifth Report. Wld Hlth Org. tech. Rep. Ser. No. 190

\section{Evaluation d'une campagne de masse antérieure contre la syphilis endémique en Bosnie-Herzé- govine}

\section{SOMMAIRE}

Une analyse des informations recueillies dans une étude séro-épidémiologique de la syphilis endémique non vénérienne en Bosnie en 1968, comparée avec les données obtenues lors d'une campagne de masse antérieure et avec les informations disponibles sur le contrôle qui a suivi cette campagne, mène à la conclusion que la dite campagne de masse a complètement interrompu la transmission de la syphilis endémique. Cette dernière s'est développée sur un fond de rapide changement socio-économique de la population affectée, allant de pair avec la création de services de santé modernes intéressant la population entière de la République de Bosnie-Herzégovine.

L'analyse des informations de base montre que ce résultat excellent a dépendu du traitement intensif de tous les cas détectés par un examen clinique et sérologique systématique de la population atteinte et des sujets qui avaient été exposés au contact de parents trouvés infectés lors de l'examen et du ré-examen fait après le traitement initial. Les ré-examens au cours de la surveillance de la maladie après la campagne ont intéressé un nombre décroissant de sujets et ont été particulièrement dirigés contre les foyers de haute prévalence trouvés lors des examens précédents. Les constatations faites à l'aide du test TPI utilisé dans l'étude séro-épidémiologique de 1968 à 1970 , indiquent que les dispositifs de diagnostic employés pendant la campagne de masse avaient été appropriés.

Dans l'introduction du présent rapport, deux questions essentielles de santé publique, en relation avec la syphilis endémique, ont été mises en évidence, principalement: "une maladie infectieuse à son stade clinique récent peut-elle être actuellement éliminée ?" et "la transmission de l'infection peut-elle être interrompue à l'aide d'une application large d'un médicament spécifique employé d'après les caractéristiques épidémiologiques de la maladie ?".

La présente étude montre qu'une maladie à son stade d'infection récente peut être éliminée et que la transmission de l'infection tréponémique peut être interrompue par une campagne de masse vigoureuse et soigneusement conduite, aidée par l'organisation d'un Service de Santé efficace de même que par une amélioration concomitante des conditions socio-économiques, comme ceci fut le cas en Bosnie-Herzégovine. 